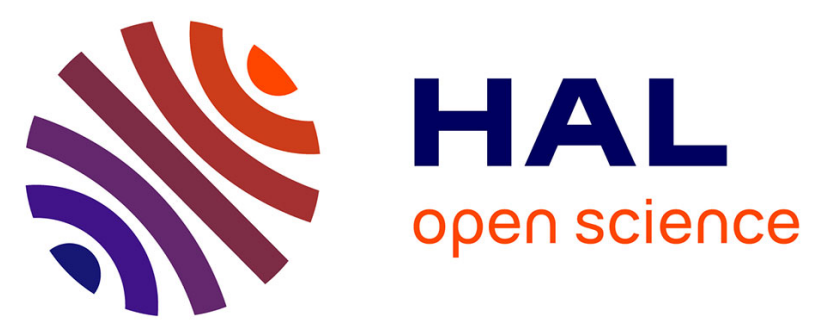

\title{
Continuous production of a biogenic ferric iron lixiviant for the bioleaching of printed circuit boards (PCBs)
} Agathe Hubau, Michel Minier, Alexandre Chagnes, Catherine Joulian, Cédric Perez, Anne-Gwenaëlle Guezennec

\section{- To cite this version:}

Agathe Hubau, Michel Minier, Alexandre Chagnes, Catherine Joulian, Cédric Perez, et al.. Continuous production of a biogenic ferric iron lixiviant for the bioleaching of printed circuit boards (PCBs). Hydrometallurgy, 2018, 180, pp.180-191. 10.1016/j.hydromet.2018.07.001 . hal-02182968

\section{HAL Id: hal-02182968 \\ https://hal.univ-lorraine.fr/hal-02182968}

Submitted on 22 Aug 2019

HAL is a multi-disciplinary open access archive for the deposit and dissemination of scientific research documents, whether they are published or not. The documents may come from teaching and research institutions in France or abroad, or from public or private research centers.
L'archive ouverte pluridisciplinaire HAL, est destinée au dépôt et à la diffusion de documents scientifiques de niveau recherche, publiés ou non, émanant des établissements d'enseignement et de recherche français ou étrangers, des laboratoires publics ou privés.

\section{(1) (1) $\$$}

Distributed under a Creative Commons Attribution - NonCommercial - NoDerivatives| 4.0 
Continuous production of a biogenic ferric iron lixiviant for the bioleaching of printed circuit boards (PCB) Agathe HUBAU ${ }^{1,2, *}$, Michel MINIER ${ }^{2}$, Alexandre CHAGNES $^{3}$, Catherine JOULIAN $^{1}$, Cédric PEREZ ${ }^{1}$, Anne-Gwenaëlle GUEZENNEC ${ }^{1}$

${ }^{1}$ BRGM, F-45060 Orléans, France

${ }^{2}$ Chimie ParisTech, PSL Research University, CNRS, Institut de Recherche de Chimie Paris (IRCP), F-75005 Paris, France

${ }^{3}$ GéoRessources - UMR CNRS 7359-CREGU-Université de Lorraine, 2 Rue du Doyen Roubault 54500, BP 10162, Vandœuvre-lès-Nancy Cedex, France

* Corresponding author E-mail address: a.hubau@brgm.fr

\begin{abstract}
Ferric iron is a low-cost oxidant frequently used in hydrometallurgy and is particularly suitable to leach various metals from printed circuit boards (PCBs). This paper presents the use of the BRGM-KCC acidophilic consortium to generate ferric iron solution in a bubble column run in continuous mode. The influence of influent ferrous iron concentration, ranging from 1 to $9 \mathrm{~g} \mathrm{~L}^{-1}$ on the bio-oxidation rate was studied in the presence of a solid support. The impacts of the quantity of solid support, the hydraulic residence time (HRT), the culture medium and the type of support were established. Stable performance was achieved over an extended period with a $\mathrm{Fe}^{2+}$ oxidation rate of $1400 \mathrm{mg} \mathrm{L}^{-1} \mathrm{~h}^{-1}$. Cryogenic scanning electron microscopy was used to observe the attachment of cells on the solid support in different operating conditions and showed that the clogging of the solid support with jarosite precipitates influenced its colonization by the micro-organisms and the stability of the bioprocess. The operating conditions, and especially the influent ferrous iron concentration and nutritive medium composition, also influenced the structure and the abundance of the microbial community.
\end{abstract}

Keywords: Bioleaching / Bio-oxidation / printed circuit boards / acidophilic 


\section{Introduction}

The metal content of spent printed circuit boards (PCBs) can reach up to $35 \%$ (in weight), including precious and strategic metals even at greater concentrations than in primary resources. For instance, gold and copper are 25 to 250 times and 20 to 40 times more concentrated in spent PCBs than in ores, respectively (Tuncuk et al., 2012). Consequently, spent PCBs are becoming a valuable resource. At the same time, a lack of an appropriate treatment could be a cause of environmental pollution.

Today, high-grade PCBs are treated by pyrometallurgy to recover valuable metals but some metals, such as aluminium, iron and precious metals, are lost in the slag during this operation (Cui and Zhang, 2008) and the energy-cost of such processes is high. Moreover, the presence of plastics raises two important issues: first, the emission of toxic dioxins and furans; and second, the presence of plastics can bring about uncontrolled temperature increases leading to smelter damages (Hagelüken, 2006). Currently, the addition of PCBs to smelter feed represents at most $15 \%$ of the mass, the rest being metal concentrates. For example, PCBs make up 14\% of the total throughput in the Noranda process in Canada and 10\% in the Umicore process in Belgium (Cui and Zhang, 2008; Ghosh et al., 2015). Due to this limitation, the quantity of PCBs that are treated annually remains low. Therefore, the design of energy-efficient and costeffective new processes for efficient metal recovery from PCBs is particularly important. Techniques based on mechanical processes and hydrometallurgy are emerging as alternative solutions.

Within this framework, biohydrometallurgy is very promising. In the literature, some studies deal with the use of bioleaching for the treatment of spent PCBs by means of acidophilic microorganisms (Brandl and al., 2001; Ilyas and al., 2010). The use of such micro-organisms, which are mainly iron and sulfur-oxidising, allows the extraction of various metals such as $\mathrm{Cu}, \mathrm{Ni}$ and $\mathrm{Zn}$. Although the mechanisms are not completely known, the following main reactions may occur:

$$
\begin{aligned}
& \mathrm{nFe}^{3+}+\mathrm{M}^{0} \rightarrow \mathrm{nFe}^{2+}+\mathrm{M}^{\mathrm{n}+} \text { (chemical) } \\
& 4 \mathrm{Fe}^{2+}+\mathrm{O}_{2}+4 \mathrm{H}^{+} \rightarrow 4 \mathrm{Fe}^{3+}+2 \mathrm{H}_{2} \mathrm{O} \text { (biological) }
\end{aligned}
$$

The main issue raised by research studies dedicated to the development of bioleaching processes for PCBs treatment is linked to the reproducibility of the results, mainly because of the large heterogeneity of PCBs that leads to large variation of sample composition. Most studies dedicated to acidophilic bioleaching of spent PCBs to date have been performed in simple shake flasks and the quantity of PCBs added for each batch test is often too low to be 
representative of the whole composition of the PCB sample. Moreover, the results are highly variable as important parameters, such as dissolved oxygen concentration, $\mathrm{pH}$ or microorganisms are diverse. Figure 1 illustrates the discrepancy in copper bioleaching yields reported in the literature for spent PCBs in shake flask and reactor studies.

Finally, the addition point of raw material after inoculation influences greatly PCB bioleaching efficiency. This parameter appears particularly important as PCBs may be responsible for the inhibition of microbial growth and activity (Liang et al., 2013). Staggering the production of the lixiviant and the addition of the e-waste in a two-step process can greatly increase leaching rates (Yang et al., 2009; Guezennec et al., 2015). However, this requires the establishment of a stable steady-state operation in the first stage where biomass production and ferrous iron biooxidation occur (Reaction 2). The literature shows that a vast number of iron bio-oxidation studies in continuous mode have been done to develop a large range of applications. Some studies are summarised in Table 1. In this Table, the study duration is the time before authors change any parameters once steady state is reached. Most of these works investigated multiple parameters to avoid kinetic limitations and to achieve the highest bio-oxidation rate. The first parameter is the characteristics of the influent, i.e. pH (Kaksonen et al., 2014a; Kinnunen and Puhakka, 2005) and ferrous iron concentration (Gómez and Cantero, 2003) since these parameters influence significantly the kinetics of bio-oxidation. The second parameter is the composition of the gas flow to avoid any limitation in carbon dioxide (required for bacterial growth, as it is the sole carbon source available) and/or oxygen (required for microbial oxidation of ferrous iron, see Reaction 1). Bastías and Gentina (2010) improved their chemostat performance by enriching air with $4 \% \mathrm{CO}_{2}$. Kinnunen and Puhakka (2004) detected an oxygen limitation when using air and used a $99.5 \% \mathrm{O}_{2} / 0.5 \% \mathrm{CO}_{2}$ gas mixture to obtain a maximal oxidation rate of $26.4 \mathrm{~g} \mathrm{~L}^{-1} \mathrm{~h}^{-1}$. This parameter is closely linked to the presence and the type of solid support, which will impact the gas-liquid mass transfer. First studies were performed without using solid support but performance was limited due to limited biomass and cell wash out at low hydraulic residence times (HRT; Halfmeier et al., 1993a). Consequently, many solid supports were developed and investigated (Grishin and Tuovinen, 1988), e.g. polystyrene (Karamanev and Nikolov, 1986), quartz sand (Halfmeier et al., 1993b), Ni-alloy fibres (Gómez and Cantero, 2003) and activated charcoal (Kinnunen and Puhakka, 2004). The goal was to obtain large surface areas and high numbers of attached cells without slowing down mass transfer. Activated charcoal was reported as one of the best solid supports in terms of biooxidation performance due to its porosity which enables the retention quantities of large 
biomass (Jensen and Webb, 1995). Grishin and Tuovinen (1988) reported a maximal oxidation rate of $52.6 \mathrm{~g} \mathrm{~L}^{-1} \mathrm{~h}^{-1}$ in a bioreactor with $50 \mathrm{~mL}$ of activated charcoal.

However, due to the high concentrations of ferric iron, Ebrahimi et al. (2005) suggested that the presence of jarosite precipitates in the bioreactor modifies the bio-oxidation rates and yields over long periods of time and affects mass transfer near the solid support. The formation of jarosite precipitates was extensively described (Kaksonen et al., 2014c); the following reaction occurs:

$$
\mathrm{A}^{+}+3 \mathrm{Fe}^{3+}+2 \mathrm{SO}_{4}^{2-}+6 \mathrm{H}_{2} \mathrm{O} \rightarrow \mathrm{AFe}_{3}\left(\mathrm{SO}_{4}\right)_{2}(\mathrm{OH})_{6}+6 \mathrm{H}^{+}
$$

Where $\mathrm{A}^{+}$is a cation (potassium $\mathrm{K}^{+}$, sodium $\mathrm{Na}^{+}$, ammonium $\mathrm{NH}_{4}{ }^{+}$, hydronium $\mathrm{H}_{3} \mathrm{O}^{+}$).

During 6 months, Halfmeier et al. (1993) operated a fixed-bed reactor in continuous mode and revealed transport limitation and long-term stability issues. Kinnunen and Puhakka (2004) highlighted the influence of jarosite accumulation on oxidation performance in a fluidized-bed reactor, with a majority of cells attached on jarosite, creating instabilities when removing these precipitates. They revealed some difficulties to maintain constant jarosite formation rate, and thus, to maintain stable performance (Kinnunen and Puhakka, 2005). Recently, Kaksonen et al. (2014a, 2014c) investigated the use of these precipitates as solid support. Ebrahimi et al. (2005) used this method to develop an airlift reactor that presented stable performance over long periods of time to establish a process of $\mathrm{H}_{2} \mathrm{~S}$ removal. The use of a settler (Kaksonen et al., 2014a, 2014c) to remove excess sludge maintained stable performance.

This paper reports the performance and the limitations obtained for the bio-oxidation of ferrous iron in a bubble column run in continuous mode, which will be used as the first stage of a biolixiviant reactor for leaching spent PCBs. The influence of influent ferrous iron concentration on the bio-oxidation rate was studied over an extended period of time. The influence of the type and quantity of solid support and of the medium composition on biooxidation yield were investigated. The colonization of solid support was observed by cryogenic scanning electron microscopy to understand the phenomena that affect the stability of biooxidation performance. The main objective of the study was to determine the operating parameters which enabled stable and maximal performance over a period of several weeks.

\section{Material and methods}

2.1 Growth medium and bacterial culture. The inoculum used for the cultures was obtained from the BRGM-KCC microbial consortium subcultured on pyrite tailings (Guezennec et al., 2017). The predominant micro-organisms in the culture are affiliated to the acidophilic genera Leptospirillum, Acidithiobacillus and Sulfobacillus. Two culture media were 
used: $0 \mathrm{Km}$ medium consisted of $\left(\mathrm{g} \mathrm{L}^{-1}\right): 3.70\left(\mathrm{NH}_{4}\right)_{2} \mathrm{SO}_{4}, 0.81 \mathrm{H}_{3} \mathrm{PO}_{4} 85 \%, 0.48 \mathrm{KOH}, 0.52$ $\mathrm{MgSO}_{4} .7 \mathrm{H}_{2} \mathrm{O}$, while the culture medium $0 \mathrm{Cm}$ had the same composition but only $0.4 \mathrm{~g} \mathrm{~L}^{-1}$ $\left(\mathrm{NH}_{4}\right)_{2} \mathrm{SO}_{4}$. Ferrous iron was added as $\mathrm{FeSO}_{4} \cdot 7 \mathrm{H}_{2} \mathrm{O}$ to obtain ferrous iron concentrations ranging from 1 to $9 \mathrm{~g} \mathrm{~L}^{-1}$. $1 \mathrm{Km}$ and $9 \mathrm{Km}$ denote $0 \mathrm{Km}$ culture media containing 1 and $9 \mathrm{~g} \mathrm{~L}^{-1}$ of ferrous iron, while $1 \mathrm{Cm}$ and $9 \mathrm{Cm}$ denote $0 \mathrm{Cm}$ culture media containing 1 and $9 \mathrm{~g} \mathrm{~L}^{-1}$ of ferrous iron respectively. Growth media were adjusted to $\mathrm{pH} 1.2$ using concentrated $\mathrm{H}_{2} \mathrm{SO}_{4}$.

2.2 Experimental setup. Continuous culture experiments were carried out in two separate $150 \mathrm{~mL}$ (working volume) bubble columns (4.5 cm in diameter, $30 \mathrm{~cm}$ in height) immersed in a water bath to maintain the temperature at $36{ }^{\circ} \mathrm{C}$. A schematic diagram of the bubble column used for this study is given in Figure 2. The growth medium was fed continuously to the bottom of the bubble column and the effluent removed at the desired dilution rate by means of variablespeed pumps. The cell suspension was aerated with air flow between 20 and $30 \mathrm{~L} \mathrm{~h}^{-1}$ (2.2 to $3.3 \mathrm{vvm})$. Air was enriched with $\mathrm{CO}_{2}$ to obtain a partial pressure of $1 \% \mathrm{CO}_{2}$. Ferrous-iron oxidation kinetics was investigated at various residence times, ranging from 1 to $18 \mathrm{~h}$. To avoid cell wash-out, solid support was introduced in the bubble column, with an apparent volume varying from 33 to $100 \mathrm{~mL}$. Solid supports were either activated charcoal (Organosorb11® from Desotec) or polyvinyl chloride beads (Tefanyl® ${ }^{\circledR}$ VR VRGR 366 from Mitsubishi Chemical Performance Polymers). The latter were used as received while the charcoal was washed with $5 \mathrm{~mL} \mathrm{~g}^{-1}$ of water and $1 \mathrm{~mL} \mathrm{~g}^{-1}$ of diluted sulfuric acid $(\mathrm{pH} 1.3)$, dried at $40^{\circ} \mathrm{C}$ for 20 hours and sieved to remove particles smaller than $1 \mathrm{~mm}$ prior to use. The bioreactor was inoculated with the BRGM-KCC culture at $10 \% \mathrm{v} / \mathrm{v}$. The bubble column was first operated in batch mode in order to establish the biomass and then switched into continuous mode when the redox potential reached $900 \mathrm{mV}$ vs. SHE. All experiments were performed in non-sterile conditions, to suit more accurately the industrial reality.

Finally, biotic and abiotic shake flasks experiments were done to determine the chemical oxidation of ferrous iron by the activated charcoal itself. Flasks $(250 \mathrm{~mL})$ contained $100 \mathrm{~mL}$ 9Cm medium with $10 \mathrm{~g}$ of activated charcoal. Biotic tests were inoculated with $10 \%(\mathrm{v} / \mathrm{v})$ BRGM-KCC. Abiotic shake flasks were autoclaved with activated charcoal, 9Cm medium was filter sterilized ( $0.2 \mu \mathrm{m}$ syringe filter from ClearLine in cellulose acetate) and manipulations were performed under a laminar air flow hood.

2.3 Analytical techniques. Oxygen and carbon dioxide concentrations in the off-gas from the bioreactor were analysed by using ADC MGA 3000 Multi-Gas Analyzer (Analytical Development Company Ltd). Total iron concentration was determined by flame atomic absorption spectroscopy (AAS) using a Varian SpectrAA-300. Ferrous iron concentration was 
determined by using the correlation between redox potential and total iron concentration as reported by Yue et al. (Yue et al., 2014). Estimated values of ferrous iron concentration deduced from this correlation were occasionally confirmed experimentally by performing cerium (IV) titration with a Metrohm titrode (Pt-pH) in sulfuric acid medium (Yue et al., 2016).

\subsection{Bacterial community monitoring.}

2.4.1 Cell counting. The number of micro-organisms in the supernatant was monitored by counting on Thoma cell counting chamber. The same methodology was used to count attached cells on the solid support, after cell detachment performed by slowly shaking with a mixing shaker (Heidolph Reax 2) at minimum speed (24 rpm) $500 \mathrm{mg}$ of solid support in $1.5 \mathrm{~mL}$ of fresh acidic medium $(0 \mathrm{Km}$ with $\mathrm{pH}<2)$ with $0.25 \% \mathrm{v} / \mathrm{v}$ Tween 20 (from Sigma Aldrich), for 1 hour.

2.4.2 Cryogenic scanning electron microscopy (Cryo-SEM). This method was used to observe the attachment of cells onto the solid support without prior steps of preparation. Fresh aliquots of solids sampled from the bubble column were introduced on a copper frame with carbon paste. Samples were immersed into liquid nitrogen at $-176{ }^{\circ} \mathrm{C}$ and a pressure depression enabled to reach $-210{ }^{\circ} \mathrm{C}$ (slush nitrogen). From this point, samples were set under vacuum and transferred into the SEM (Hitachi S-4500 field-emission operated at $1 \mathrm{kV}$ ). They were warmed to $-70{ }^{\circ} \mathrm{C}$ to remove ice that was formed on the sample due to moisture condensation and cooled to $-105^{\circ} \mathrm{C}$ for observations. Detection of secondary electrons was performed on the surface or inside samples after cryo-fracturing. Energy dispersive X-ray spectroscopy (EDX) was used to characterize the sample composition with SEM operated at 5 or $15 \mathrm{kV}$.

2.4.3 DNA extraction and capillary electrophoresis-single strand conformational polymorphism (CE-SSCP) monitoring of the bacterial community structure. The CE-SSCP technique was used on polymerase chain reaction (PCR) product of $16 \mathrm{~S}$ rRNA gene to obtain a diversity profile and to determine relative abundances of the detected bacterial strains. Samples containing $0.5 \mathrm{~mL}$ solid support or $2 \mathrm{~mL}$ liquid phase were taken from the bubble column. Solid samples and pellets (from centrifugation of the liquid samples for 10 minutes at $14000 \mathrm{~g})$ were washed by re-suspension in Tris buffer $(100 \mathrm{mM}, \mathrm{pH} 8)$ until $\mathrm{pH}$ reached around 7. Genomic DNA was extracted with the FastDNA Spin Kit for Soil and using the manufacturer's protocol (MP Biomedicals) with a FastPrep ${ }^{\circledR}-24$ at a speed of $5 \mathrm{~m} \mathrm{~s}^{-1}$ for $30 \mathrm{~s}$. Amplification of the $16 \mathrm{~S}$ rRNA gene from DNA extracts was performed with C-1000 thermocycler (Biorad) with the w49 forward primer and the 5'-end FAM-labeled w34 primer, as in Hedrich et al. (2016). For CE-SSCP analysis, one microliter of 5- to 500-fold diluted PCR product, $0.4 \mu \mathrm{L}$ of Genescan-600 LIZ internal standard (Applied Biosystems) and 18.6 $\mu \mathrm{L}$ of 
deionized formamide HiDi (Applied Biosystems) were heated for 5 minutes at $95{ }^{\circ} \mathrm{C}$ for denaturation and immediately cooled on ice for 10 minutes. Fragment analyses were conducted with the ABI Prism 310 (Applied Biosystems). The software GeneScan (Applied Biosystems) was used to realign the peak profiles based on internal standard migration, assign peak position and calculate relative abundances on the basis of peak areas.

\section{Results}

\subsection{The influence of ferrous iron concentration on bio-oxidation}

Activated charcoal produced from black granular coal was chosen as support for this work because high bio-oxidation rates can be achieved with this type of support (Jensen and Webb, 1995), especially due to its high specific area of $950 \mathrm{~m}^{2} \mathrm{~g}^{-1}$. It should be noted that the rate of the chemical oxidation of ferrous iron into ferric iron in the presence of activated charcoal is very low, as demonstrated by the studies of Kuznetsova et al. (1995) and Ahumada et al. (2002) with severe conditions (high temperature and $\mathrm{O}_{2}$ pressure). In our conditions, measures in sterile shake flasks in $9 \mathrm{Cm}$ medium gave a chemical oxidation rate reaching $65 \mathrm{mg} \mathrm{L}^{-1} \mathrm{~h}^{-1}$ with clean activated charcoal. This rate was much lower than the one in biotic shake flasks, with biooxidation rates easily reaching $240 \mathrm{mg} \mathrm{L}^{-1} \mathrm{~h}^{-1}$. It confirms that this material is mainly acting as a solid support for bacteria, and its ability to catalyse ferrous iron oxidation is negligible compared to bio-oxidation.

In order to examine the kinetics of bio-oxidation at different influent ferrous iron concentrations, $15 \mathrm{~g}$ of activated charcoal were introduced in the bioreactor and the HRT was set to $12 \mathrm{~h}$. This mass of activated charcoal corresponded to an apparent volume of $33 \mathrm{~mL}$. Table 2 shows the bio-oxidation yield and rate obtained in these conditions with ferrous iron concentration in the influent medium ranging from 1 to $9 \mathrm{~g} \mathrm{~L}^{-1}$.

The maximum bio-oxidation rate obtained was $375 \mathrm{mg} \mathrm{L}^{-1} \mathrm{~h}^{-1}$ with an influent concentration of $4.5 \mathrm{~g} \mathrm{~L}^{-1}$ of ferrous iron. This maximal oxidation rate was very low compared to those reported in the literature. At higher influent ferrous iron concentrations, both the bio-oxidation yield and rate were lower. Moreover, substantial variations in these rates were observed with the same operating conditions.

Bio-oxidation performance as a function of HRT is presented for bioreactors with 1 and $9 \mathrm{~g}$ $\mathrm{L}^{-1}$ influent ferrous iron in Figure 3. For fixed operating conditions, performance were not stable even at 10 HRT. Consequently, each dot of the figure, which represents the bio-oxidation yield or rate for one fixed HRT, depicts the most common value obtained in these fixed operating conditions. Error bars depict the range of all other obtained values in such conditions. Figure 3 
shows large discrepancies in bio-oxidation yield and rate when $9 \mathrm{~g} \mathrm{~L}^{-1}$ ferrous iron was used whatever the HRT. This was mainly due to precipitate formation on the solid support (see below). At $1 \mathrm{~g} \mathrm{~L}^{-1}$ ferrous iron, between $80 \%$ and $100 \%$ bio-oxidation yield was obtained for high HRT. However, when the HRT decreased below 4 hours, iron bio-oxidation yield decreased sharply. A maximum oxidation rate of $450 \mathrm{mg} \mathrm{L}^{-1} \mathrm{~h}^{-1}$ was obtained at $1 \mathrm{~g} \mathrm{~L}^{-1}$ ferrous iron and HRT of 2 hours.

\subsection{The influence of the quantity of activated charcoal on bio-oxidation}

In order to minimize the instabilities obtained at high influent ferrous iron concentrations, the impact of the quantity of solid support was investigated. The amount of activated charcoal influences the amount of biomass attached onto and into the solid, and therefore, the performance of the bioreactor. Table 3 shows the bio-oxidation rate for both influent ferrous iron concentrations $\left(1 \mathrm{~g} \mathrm{~L}^{-1}\right.$ and $\left.9 \mathrm{~g} \mathrm{~L}^{-1} \mathrm{Fe}^{2+}\right)$ at $6 \mathrm{~h} \mathrm{HRT}$.

The quantity of activated charcoal at $1 \mathrm{~g} \mathrm{~L}^{-1}$ did not seem to influence iron oxidation since $100 \%$ bio-oxidation was obtained in all cases at $6 \mathrm{~h}$ HRT. Higher oxidation rates were observed at influent ferrous concentration of $9 \mathrm{~g} \mathrm{~L}^{-1}$ when larger quantities of activated charcoal were used; however, the performance was still not stable. It is interesting to highlight that, at fixed HRT, the addition of activated charcoal into the bioreactor was responsible for an instantaneous increase in bio-oxidation yield and rate followed by a gradual decrease (data not shown). Figure 4 shows lower instabilities when larger amounts of activated charcoal were used at $9 \mathrm{~g} \mathrm{~L}^{-1}$. The iron bio-oxidation yield gradually decreased with decreasing HRT and oxidation rate varied between 400 and $700 \mathrm{mg} \mathrm{L}^{-1} \mathrm{~h}^{-1}$.

\subsection{The influence of the growth media composition on bio-oxidation}

Silverman and Lundgren (1959) detailed the composition of a growth medium (9K) adapted to the growth of acidophilic microorganisms, e.g. Acidithiobacillus ferrooxidans. Collinet-Latil (1989) modified this medium to obtain optimal bioleaching performance with the BRGM-KCC consortium. In the present study, this medium $(0 \mathrm{Km})$ was compared with the $0 \mathrm{Cm}$ medium, which contains the same quantities of $\mathrm{KOH}, \mathrm{H}_{3} \mathrm{PO}_{4}$ and $\mathrm{MgSO}_{4} .7 \mathrm{H}_{2} \mathrm{O}$ and ten times less $\left(\mathrm{NH}_{4}\right)_{2} \mathrm{SO}_{4}$ in the presence of $1 \mathrm{~g} \mathrm{~L}^{-1}$ or $9 \mathrm{~g} \mathrm{~L}^{-1}$ ferrous iron and $15 \mathrm{~g}$ or $30 \mathrm{~g}$ of activated charcoal, respectively (Figures 5 and 6).

Results obtained with both media were quite similar at $1 \mathrm{~g} \mathrm{~L}^{-1}$ ferrous iron but better performance were obtained with the $1 \mathrm{Cm}$ medium at low residence time (1.1 hour): the maximal oxidation rate increased from 450 to $900 \mathrm{mg} \mathrm{L}^{-1} \mathrm{~h}^{-1}$ when nutritive medium was 
changed from $1 \mathrm{Km}$ to $1 \mathrm{Cm}$. Concerning the bioreactor with influent ferrous iron concentration of $9 \mathrm{~g} \mathrm{~L}^{-1}$, reducing the quantity of ammonium ions allowed a more stable performance at high HRT, and enabled higher iron oxidation yields. The lower ammonium concentrations may have led to a reduction in jarosite precipitation, as explained below. In 9 $\mathrm{Cm}$ medium, maximal oxidation rate reached $1400 \mathrm{mg} \mathrm{L}^{-1} \mathrm{~h}^{-1}$ at 6.3 hours HRT. In these conditions, bio-oxidation performance was within the range of the results presented in the literature (Table 1).

\subsection{The influence of the solid support on bio-oxidation}

The bio-oxidation rate in the presence of a highly porous support (activated charcoal) and a non-porous support (polyvynil chloride beads) is shown in Figures 7 and 8 with an influent ferrous iron concentration of $1 \mathrm{~g} \mathrm{~L}^{-1}$ and $33 \mathrm{~mL}$ of solid support or $9 \mathrm{~g} \mathrm{~L}^{-1}$ and $66 \mathrm{~mL}$ of solid support, respectively. The same apparent volume was used to compare both supports and both bioreactors were first operated in batch mode during $45 \mathrm{~h}$ to favour the attachment of the biomass. At $1 \mathrm{~g} \mathrm{~L}^{-1}$ ferrous iron, similar performance was obtained with both supports at high HRT (HRT > 2 h). However, the bio-oxidation rate was obviously affected by the type of solid support at low HRT (1h): it sharply decreased from $900 \mathrm{mg} \mathrm{L}^{-1} \mathrm{~h}^{-1}$ to $500 \mathrm{mg} \mathrm{L}^{-1} \mathrm{~h}^{-1}$ with the use of PVC beads. The performance notably decreased at $9 \mathrm{~g} \mathrm{~L}^{-1}$ with PVC as less than $20 \%$ of influent ferrous iron was oxidized under such conditions whatever the residence time. The lack of porosity of PVC support was probably not favourable to the development of attached biomass in the bioreactor, since available surface area for cells attachment was low.

\subsection{The characteristics of solid support and bacterial community structure during bio-} oxidation

3.5.1 The influence of operating conditions on the solid support. Cryo-SEM was used to observe the colonization of activated charcoal particles by bacteria. Such a technique is particularly suitable for this study since it allows the observation of fresh biological materials as no dehydration step is required during sample preparation and it is possible to obtain highresolution images at low voltage. This method also enables the breaking of the charcoal particles into sub-particles without damaging the biofilm in order to observe the interior of porous material: an example of ore breakage was described by Kelly and Burgio (1983).

Figures 9-11 show Cryo-SEM pictures inside and outside charcoal particles in biotic conditions in the presence of 1 and $9 \mathrm{~g} \mathrm{~L}^{-1}$ ferrous iron and in abiotic conditions in the presence of $9 \mathrm{~g} \mathrm{~L}^{-1}$ ferric iron in $0 \mathrm{Km}$ culture medium. Figure 9A shows the presence of many bacteria inside activated charcoal particles in the $1 \mathrm{Km}$ media. Cells seemed to be attached on the surface 
into the pores of the solid support. An organic substance was observed around these cells by Cryo-SEM but its fast degradation by the electron beam prevented the acquisition of any pictures. It was supposed that this substance was composed of extracellular polymeric substances. Only very few cells were observed in the presence of $9 \mathrm{~g} \mathrm{~L}^{-1}$ ferrous iron and none are visible on Figure 9B. Figures 9B and 9C show the presence of an organic framework but this framework seemed different from the one observed in Figure 9A since its resistance against electron beam was greater. This organic framework is likely composed of bitumen substances given that charcoal is a bituminous compound.

Figure 10 shows the presence of precipitates onto the particle surface in all samples. These precipitates formed a layer on the solid support, which seemed to be more spread in samples colonized under biotic conditions in the presence of $9 \mathrm{~g} \mathrm{~L}^{-1}$ ferrous iron (Figure 10B) and in Erlenmeyer under abiotic conditions in the presence of $9 \mathrm{~g} \mathrm{~L}^{-1}$ ferric iron (Figure 10C) when compared to $1 \mathrm{Km}$ medium (Figure 10A). It is interesting to highlight that the activated charcoal surface seemed to be entirely coated by precipitates in the presence of $9 \mathrm{~g} \mathrm{~L}^{-1}$ iron (Figures 10B and 10C) while less precipitate covered the charcoal surface in the presence of $1 \mathrm{~g} \mathrm{~L}^{-1}$ iron (Figure 10A), leading to the formation of small pores.

The edge of a representative charcoal particle after colonization in a growth medium containing $9 \mathrm{~g} \mathrm{~L}^{-1}$ ferrous iron is shown in Figure 11. Pseudocubic structures, which are attributed to ammonium jarosite precipitation (Kaksonen et al., 2014), were observed in the particle pores. It can be inferred that the precipitate was actually a mixture of ammonium jarosite (pseudocubic structure) and potassium jarosite since EDX analyses demonstrated the presence of potassium and sulfate (Figure 12).

3.5.2 Bacterial community structure. Microbial diversity profiles were determined in bioreactors by $16 \mathrm{~S}$ rRNA gene CE-SSCP. A comparison was performed between solid and liquid phases in bioreactors for two different influent ferrous iron concentrations $\left(1 \mathrm{~g} \mathrm{~L}^{-1}\right.$ with $15 \mathrm{~g}$ of activated charcoal and $9 \mathrm{~g} \mathrm{~L}^{-1}$ with $30 \mathrm{~g}$ of activated charcoal) for HRT ranging from 1 to 10 hours (Figure 13). Results implied that conditions in the bioreactor were unsuitable for the growth of Acidithiobacillus caldus, as it remained undetected despite this bacterium being a member of the BRGM-KCC consortium initially used to inoculate the bioreactor. This can be explained by the absence of reduced sulfur compounds in the bioreactor since Acidithiobacillus caldus is a sulfur-oxidizing bacterium. Likewise, Sulfobacillus thermosulfidooxidans was not detected in any samples. The temperature maintained at $36{ }^{\circ} \mathrm{C}$ in the bioreactor was probably too low since the optimal growth temperature is $51^{\circ} \mathrm{C}$ for this bacterium (Watling et al., 2008). 

BRGM-KCC consortium, were present in the solid and the liquid phases in the bioreactor but their relative abundance varied when the operating conditions changed. Especially, influent ferrous iron concentration seemed to have an influence on the bacterial growth since $9 \mathrm{~g} \mathrm{~L}^{-1}$ ferrous iron favoured the growth of Sulfobacillus benefaciens, with an average proportion of $60 \%$, while $1 \mathrm{~g} \mathrm{~L}^{-1}$ favoured Leptospirillum ferriphilum growth, with an average proportion of $80 \%$. This may be explained due to the higher affinity for the ferrous iron substrate and greater tolerance of ferric iron of L. ferriphilum over Sulfobacillus spp. (Norris, 2007). The proportions of these two organisms were similar in liquid and solid phases. Two unknown micro-organisms were detected in the bioreactor at $9 \mathrm{~g} \mathrm{~L}^{-1}$ ferrous iron for 3.5 and 5.1 hours. One of these was also detected in the other bioreactor at $1 \mathrm{~g} \mathrm{~L}^{-1}$ ferrous iron.

Finally, cell distribution between solid and liquid phases was determined in the same conditions as the previous characterization of diversity profiles. Figure 14 gives the distribution for both bioreactors. When influent ferrous iron concentration was $1 \mathrm{~g} \mathrm{~L}^{-1}$, the number of cells remained stable for HRT varying between 1 and 3 hours; the cells were also well distributed between the solid and the liquid phases. For the same iron concentration and HRT of 6.4 hours, the number of cells increased noticeably (at least by $0.5 \mathrm{Log}$ ) and a large proportion of cells were attached onto activated charcoal. In the presence of $9 \mathrm{~g} \mathrm{~L}^{-1}$ ferrous iron in the influent, the increase in cell number at high HRT was less than on $1 \mathrm{~g} \mathrm{~L}^{-1}$ ferrous iron and the cells were more or less equally distributed between the liquid and the solid phases. For HRT of 6 hours, the total cell number was much lower compared to the results obtained at $1 \mathrm{~g} \mathrm{~L}^{-1} \mathrm{Fe}^{2+}$ whereas the cell number was of the same order of magnitude for lower HRT in both conditions. It must be noted that these data are only an estimate of the number of cells in the bioreactor given the low accuracy for cell counting (inaccuracy arose from the difficulty to collect all cells from activated charcoal and from counts on Thoma cell chamber).

\section{Discussion}

Observations with Cryo-SEM highlighted the fact that activated charcoal from the bioreactor containing $9 \mathrm{~g} \mathrm{~L}^{-1}$ ferrous iron was less colonized than in the presence of $1 \mathrm{~g} \mathrm{~L}^{-1}$ ferrous iron. Furthermore, Cryo-SEM demonstrated that activated charcoal particles from 9Km bioreactor were entirely coated with precipitates, while particles from $1 \mathrm{Km}$ bubble column were only partially clogged. Consequently, one hypothesis is that instabilities in $9 \mathrm{Km}$ bioreactor performance resulted from the presence of precipitates, which coat the charcoal surface and cause difficulties for the bacterial attachment. For unchanged operating conditions (fixed HRT), 
this clogging phenomenon seemed to occur according to the following cycle: (i) High biooxidation yield and rate were observed since ferrous iron was intensively oxidized to ferric iron by the cells, which initially colonized the pores of activated charcoal; (ii) Activity of the bacteria decreased because of limitation of the diffusion of nutrients, carbon dioxide, oxygen and ferrous iron resulting from the accumulation of potassium jarosite and ammonium jarosite that coated the external charcoal surface (cf Reaction 3); (iii) Attrition between the particles was responsible for coating destruction, which led to an increase in bacterial activity, and therefore, an increase in bio-oxidation yield and rate until new jarosite precipitation phenomena occurred. The age of solid support greatly affected the performance. It was thus difficult to determine accurately the cell distribution between the liquid and the solid phases since the clogging phenomenon and the high porosity of activated charcoal limited the cell collecting procedure.

This hypothesis could explain the difference in diversity profiles between both bioreactors: Sulfobacillus benefaciens was able to take advantage of different energy and carbon sources, as it is a mixotrophic species (Johnson and al., 2008). If carbon dioxide and ferrous iron were not available due to the coating of the solid support, this species could use cellular waste to survive, at the expense of Leptospirillum ferriphilum, which is a strict autotroph (Mi and al., 2011).

It is consistent with results obtained when the growth medium composition was changed: the decrease in ammonium concentration limited ammonium jarosite precipitation, thus limiting the coating of solid support. It enabled more stable performance. In these conditions, maximal oxidation rates were obtained at $1400 \mathrm{mg} \mathrm{L}^{-1} \mathrm{~h}^{-1}$ in the presence of $9 \mathrm{~g} \mathrm{~L}^{-1}$ ferrous iron in the influent. In the literature, it is reported that the stability of jarosite depends on the standard enthalpy of formation. Thus, potassium jarosite is more stable than sodium and hydronium jarosite, which are more stable than ammonium jarosite (Gaboreau and Vieillard, 2004; Gramp et al., 2008; Kaksonen et al., 2014b). Modifying the potassium concentration in the medium could improve bacteria attachment onto the pores surface of the charcoal by avoiding potassium jarosite precipitation.

The nature of the support seemed to have a high impact on bio-oxidation performance since the use of non-porous polyvinyl chloride beads reduced the iron bio-oxidation yield to less than $20 \%$ while it reached $99 \%$ in the same conditions with activated charcoal. This was probably due to a difference in porosity, which influenced the number of accessible sites for cell attachment: with $33 \mathrm{~mL}$, the accessible surface with activated charcoal is estimated to 14520 $\mathrm{m}^{2}$ while it is estimated to $0.048 \mathrm{~m}^{2}$ with PVC beads. The zeta potential of solid supports may also play a role in the attachment of acidophilic cultures, as reported by Halfmeier et al. (1993b) $:$ it is assumed that the adsorption of cells onto solid supports due to electrostatic and Van der 
Walls forces is the first step of the creation of biofilms. Acidophilic cultures, positively charged with protonation, will better adsorb to negatively charged surfaces.

Concerning these results, one way to improve the kinetics could be to change the solid support. A study with woven nylon performed by Svirko et al. (2009) give good results in terms of ferrous iron bio-oxidation rates, with $4 \mathrm{~g} \mathrm{~L}^{-1} \mathrm{~h}^{-1}$. This might be explained by the creation of a framework that enables the biomass to get attached without affecting mass transfer.

The highest oxidation rate obtained in $9 \mathrm{Cm}$ was $1400 \mathrm{mg} \mathrm{L}^{-1} \mathrm{~h}^{-1}$ at HRT of 6.3 hours. Concerning the $1 \mathrm{Cm}$ medium, the highest oxidation rate obtained was $900 \mathrm{mg} \mathrm{L}^{-1} \mathrm{~h}^{-1}$ at a minimum HRT of $1.1 \mathrm{~h}$. To go further in the design of the bubble column, it is therefore mandatory to take into account the second stage of the bioreactor. If the bubble column must regenerate high concentrations of ferric iron due to the inhibition of bacterial activity in the second stage, it is necessary to test higher influent ferrous iron concentrations and minimize ferric iron precipitation. If the bubble column aims at the development of a fresh culture with planktonic cells, the use of activated charcoal is not recommended as cells are strongly attached onto the pores surface of solid support particles.

\section{Conclusion}

To recover metals from different resources, particularly spent printed circuit boards, the production of a biogenic lixiviant solution is of great interest. However, the monitoring of the process should be controlled and the stability of this production over long periods of time is necessary. In this work, a bubble column inoculated with BRGM-KCC microbial consortium in the presence of activated charcoal was used for ferric lixiviant generation. Results were not reproducible at $9 \mathrm{~g} \mathrm{~L}^{-1}$ in $0 \mathrm{Km}$ medium and were much lower than literature oxidation rates. The use of higher quantities of activated charcoal did not improve the rates but the stability improved. The use of polyvinyl chloride beads as solid support decreased the oxidation rates. However, with a modified medium containing a ten-fold lower ammonia concentration, maximal bio-oxidation rates were obtained with activated charcoal with long-term stability: $1400 \mathrm{mg} \mathrm{L}^{-1} \mathrm{~h}^{-1}$ with $9 \mathrm{~g} \mathrm{~L}^{-1}$ ferrous iron at HRT of $6.3 \mathrm{~h}$ and $900 \mathrm{mg} \mathrm{L}^{-1} \mathrm{~h}^{-1}$ with $1 \mathrm{~g} \mathrm{~L}^{-1}$ ferrous iron at the minimal HRT experimented, $1.1 \mathrm{~h}$. These results were satisfactory since they were in the range of the kinetics found in the literature and they were maintained during extended periods of time. Cryo-SEM observations of activated charcoal particles demonstrated the presence of precipitates on the external surface of activated charcoal (ammoniojarosite and potassiojarosite). The clogging of charcoal pores was likely to explain the decrease of the bubble column performance, at $9 \mathrm{~g} \mathrm{~L}^{-1}$ particularly, by trapping cells into solid support. 
Consequently, according to the age of the support, mass transfer $\left(\mathrm{Fe}^{2+}\right.$, nutrients, $\mathrm{O}_{2}$ and $\left.\mathrm{CO}_{2}\right)$ from the liquid phase to the bacteria was reduced and oxidation kinetics were lower than expected. The microbial diversity profiles in the bioreactor were different in presence of 1 or 9 $\mathrm{g} \mathrm{L}^{-1}$ of ferrous iron : mixotrophic cells were in higher proportions in $9 \mathrm{~g} \mathrm{~L}^{-1}$ bubble column, as mass transfer were limited due to the clogging whereas autotrophic cells (particularly Leptospirillum ferriphilum) were in higher proportions in $1 \mathrm{~g} \mathrm{~L}^{-1}$ bubble column. With this knowledge, operating conditions of such a bioreactor can be adapted to be adequate to the subsequent step of the process, i.e. the leaching of PCBs.

\section{Acknowledgements}

This work was supported by the Chair "Mines Urbaines" from ParisTech foundation supported by Eco-systèmes. Authors would like to thank Christopher G. Bryan for his careful reading of the paper.

\section{References}

Ahumada, E., Lizama, H., Orellana, F., Suárez, C., Huidobro, A., Sepúlveda-Escribano, A., Rodríguez-Reinoso, F., 2002. Catalytic oxidation of Fe(II) by activated carbon in the presence of oxygen. Effect of the surface oxidation degree on the catalytic activity, Carbon, 40, 2827 2834.

Arshadi, M., Mousavi, S.M., 2014. Simultaneous recovery of $\mathrm{Ni}$ and $\mathrm{Cu}$ from computer printed circuit boards using bioleaching: Statistical evaluation and optimization, Bioresource Technology, 174, 233-242.

Arshadi, M., Mousavi, S.M., 2015. Multi-objective optimization of heavy metals bioleaching from discarded mobile phone PCBs: Simultaneous $\mathrm{Cu}$ and $\mathrm{Ni}$ recovery using Acidithiobacillus ferrooxidans, Separation and Purification Technology, 147, 210-219.

Bai, J., Gu, W., Dai, J., Zhang, C., Yuan, W., Deng, M., Luo, X., Wang, J., 2016. The catalytic role of nitrogen-doped carbon nanotubes in bioleaching copper from waste printed circuit boards, Pol. J. Environ. Stud., 25 (3), 951-957.Bas, A.D., Deveci, H., Yazici, E.Y., 2013. Bioleaching of copper from low grade scrap TV circuit boards using mesophilic bacteria, Hydrometallurgy, 138, 65-70.

Bastías, M., Gentina, J. C. , 2010. Variables affecting the growth and ferrous oxidation capacity of L. Ferrooxidans in continuous culture. Hydrometallurgy 104, 351-355. 
Brandl, H., Bosshard, R., Wegmann, M., 2001. Computer-munching microbes: metal leaching from electronic scrap by bacteria and fungi. Hydrometallurgy 59, 319-326.

465

466

Bryan, C.G., Watkin, E.L., McCredden, T.J., Wong, Z.R., Harrison, S.T.L., Kaksonen, A.H., 2015. The use of pyrite as a source of lixiviant in the bioleaching of electronic waste. Hydrometallurgy, 152, 33-43.

Chen, S., Yang, Y., Liu, C., Dong, F., Liu, B., 2015. Column bioleaching copper and its kinetics of waste printed circuit boards (WPCBs) by Acidithiobacillus ferrooxidans. Chemosphere, 141, 162-168.

Collinet-Latil, M.N., 1989. PhD thesis, Lixiviation bactérienne par Thiobacillus ferrooxidans et Thiobacillus thiooxidans d'un concentré de flottation arsénopyriteux aurifère (réfractaire à la cyanuration directe), University of cellular biology and microbiology AixMarseille.

Cui, J., Zhang, L., 2008. Metallurgical recovery of metals from electronic waste: A review. Journal of Hazardous Materials, 158, 228-256.

Ebrahimi, S., Fernandez Morales, F.J., Kleerebezem, R., Heijnen, J.J., Van Loosdrecht, M.C.M., 2005. High-Rate Acidophilic Ferrous Iron Oxidation in a Biofilm Airlift Reactor and the Role of the Carrier Material, Biotechnology and Bioengineering, 90(4), 462-472.

Gaboreau, S., Vieillard, P., 2004. Prediction of Gibbs free energies of formation of minerals of the alunite supergroup, Geochimica et Cosmochimica Acta, 68(16), 3307-3316.

Ghosh, B., Ghosh, M.K., Parhi, P., Mukherjee, P.S., Mishra, B.K., 2015. Waste Printed Circuit Boards recycling: an extensive assessment of current status, Journal of Cleaner Production, 94, 5-19.

Gómez J.M., Cantero D., 2003. Kinetic study of biological ferrous sulphate oxidation by iron-oxidising bacteria in continuous stirred tank and packed bed bioreactors, Process Biochemistry, 38, 867-87.

Gramp, J.P., Jones, F.S., Bigham, J.M. \& Tuovinen, O.H., 2008. Monovalent cation concentrations determine the types of $\mathrm{Fe}$ (III) hydroxysulfate precipitates formed in bioleach solutions, Hydrometallurgy, 94, 29-33.

Grishin, S.I., Tuovinen, O.H., 1988. Fast kinetics of $\mathrm{Fe}^{2+}$ oxidation in packed-bed reactors, Appl. Microbiol. Biotechnol., 54, 12, 3092-100. 
Gu, W., Bai, J., Dai, J., Zhang, C., Yuan, W., Wang, J., Wang, P., Zhao, X., 2014. Characterization of extreme acidophile bacteria (Acidithiobacillus ferrooxidans) bioleaching copper from flexible PCB by ICP-AES, Journal of Spectroscopy, 2014, 269351.

Gu, W., Bai, J., Dong, B., Zhuang, X., Zhao, J., Zhang, C., Wang, J., Shih, K., 2017 a. Catalytic effect of graphene in bioleaching copper from waste printed circuit boards by Acidithiobacillus ferrooxidans, Hydrometallurgy, 171, 172-178.

Gu, W., Bai, J., Dong, B., Zhuang, X., Zhao, J., Zhang, C., Wang, J., Shih, K., 2017 b. Enhanced bioleaching efficiency of copper from waste printed circuit board driven by nitrogendoped carbon nanotubes modified electrode, Chemical Engineering Journal, 324, 122-129.

Guay, R., Silver, M., Torma, A.E., 1977. Ferrous iron oxidation and uranium extraction by Thiobacillus ferrooxidans, Biotech. Bioeng. 19, 727-740.

Guezennec, A.G., Bru, K., Jacob, J., d'Hugues, P., 2015. Co-processing of sulfidic mining wastes and metal-rich post-consumer wastes by biohydrometallurgy, Minerals Engineering, 75, $45-53$.

Guezennec, A.G., Joulian, C., Jacob, J., Archane, A., Ibarra, D., de Buyer, R., Bodénan, F., d'Hugues, P., 2017. Influence of dissolved oxygen on the bioleaching efficiency under oxygen enriched atmosphere, Miner. Eng. 106, 64-70.

Halfmeier, H., Schafer-Treffenfeldt, W., Ressus, M., 1993a. Potential of Thiobacillus ferrooxidans for waste gas purification: Part 1. Kinetics of continuous ferrous iron oxidation, Appl. Microbial. Biotechnol. 40, 416-420.

Halfmeier, H., Schafer-Treffenfeldt, W. \& Ressus, M., 1993b. Potential of Thiobacillus ferrooxidans for waste gas purification: Part 2. Increase in continuous ferrous iron oxidation kinetics using immobilized cells, Appl. Microbial. Biotechnol. 40, 582-587.

Hedrich, S., Guezennec, A.-G., Charron, M., Schippers, A., Joulian, C., 2016. Quantitative Monitoring of Microbial Species during Bioleaching of a Copper Concentrate. Frontiers in Microbiology 07, 2044.

Hong, Y., Valix, M., 2014. Bioleaching of electronic waste using acidophilic sulfur oxidising bacteria, Journal of Cleaner Production, 65, 465-472.

Ilyas, S., Anwar, M.A., Niazi, S.B., Ghauri M.A., 2007. Bioleaching of metals from electronic scrap by moderately thermophilic acidophilic bacteria. Hydrometallurgy, 88, 180188. 
Ilyas, S., Lee, J.C., 2014. Bioleaching of metals from electronic scrap in a stirred tank reactor, Hydrometallurgy, 149, 50-62.

Ilyas, S., Lee, J.C., Chi, R.A., 2013. Bioleaching of metals from electronic scrap and its potential for commercial exploitation. Hydrometallurgy, 131-132, 138-143.

Ilyas, S., Ruan, C., Bhatti, H. N., Ghauri, M. A., Anwar, M. A., 2010. Column bioleaching of metals from electronic scrap. Hydrometallurgy 101, 135-140.

Işildar, A., van de Vossenberg, J., Rene, E.R., van Hullebusch, E.D., Lens, P. N. I., 2015. Two-step bioleaching of copper and gold from discarded printed circuit boards (PCB). Waste Management, 57, 149-157.

Jensen, A.B., Webb, C., 1995. Ferrous sulphate oxidation using Thiobacillus ferrooxidans: a review, Process Biochemistry, 30, 3, 225-236.

Johnson, D. B., Joulian, C., d'Hugues, P., Hallberg, K. B., 2008. Sulfobacillus benefaciens sp. nov., an acidophilic facultative anaerobic Firmicute isolated from mineral bioleaching operations. Extremophiles 12, 789-798.

Kaksonen, A.H., Morris, C., Rea, S., Li, J., Wylie, J., Usher, K.M., Ginige, M.P., Cheng, K.Y., Hilario, F. \& du Plessis, C.A., 2014a. Biohydrometallurgical iron oxidation and precipitation: Part I - Effect of $\mathrm{pH}$ on process performance, Hydrometallurgy, 147-148, 255263.

Kaksonen, A.H., Morris, C., Rea, S., Li, J., Usher, K.M., McDonald, R.G., Hilario, F., Hosken, T., Jackson, M. \& du Plessis, C.A., 2014b. Biohydrometallurgical iron oxidation and precipitation: Part II - Jarosite precipitate characterization and acid recovery by conversion to hematite, Hydrometallurgy, 147-148, 264-272.

Kaksonen, A.H., Morris, C., Hilario, F., Rea, S. M., Li, J., Usher, K.M., Wylie, J., Ginige, M.P., Cheng, K.Y. \& du Plessis, C., 2014c. Iron oxidation and jarosite precipitation in a twostage airlift bioreactor, Hydrometallurgy, 150, 227-235.

Karamanev, D.G., Nikolov, L.N., 1988. Influence of Some Physicochemical Parameters on Bacterial Activity of Biofilm: Ferrous Iron Oxidation by Thiobacillus ferrooxidans, Biotechnology and Bioengineering, 31, 295-299.

Karwowska, E., Andrzejewska-Morzuch, D., Łebkowska, M., Tabernacka, A., Wojtkowska, M., Telepko, A., Konarzewska, A., 2014. Bioleaching of metals from printed circuit boards supported with surfactant-producing bacteria, Journal of Hazardous Materials, 264, 203-210. 
Kelly, W.C., Burgio, P.A., 1983. Cryogenic scanning electron microscopy of fluid inclusions in ore and gangue minerals, Economic Geology, 78, 1262-1267.

Kinnunen, P.H.M., Puhakka, J.A., 2004. High-Rate Ferric Sulfate Generation by a Leptospirillum ferriphilum-Dominated Biofilm and the Role of Jarosite in Biomass Retainment in a Fluidized-Bed Reactor, Biotechnology and Bioengineering, 85(7), 697-705.

Kinnunen, P.H.M. \& Puhakka, J.A., 2005. High-rate iron oxidation at below pH 1 and at elevated iron and copper concentrations by a Leptospirillum ferriphilum dominated biofilm, Process Biochemistry, 40, 3536-3541.

Kuznetsova, N.I., Likholobov, V.A., Gurrath, M., Boehm, H.P., 1995. Promotion effect of carbon on the oxidation of ferrous ions by oxygen in the presence of sodium nitrite, Applied Catalysis A/General, 128, 41-52.

Liang, G., Mo, Y., Zhou, Q., 2010. Novel strategies of bioleaching metals from printed circuit boards (PCBs) in mixed cultivation of two acidophiles, Enzyme and Microbial Technology, 47, 322-326.

Liang, G., Tang, J., Liu, W., Zhou, Q., 2013. Optimizing mixed culture of two acidophiles to improve copper recovery from printed circuit boards (PCBs). Journal of Hazardous Materials, 250-251, 238-245.

Liang, G., Ti, P., Liu, W., Wang, B., 2016. Enhanced bioleaching efficiency of copper from waste printed circuit boards (PCBs) by dissolved oxygen-shifted strategy in Acidithiobacillus ferrooxidans. J Mater Cycles Waste Manag, 18, 742-751.

MacDonald, D.G., Clark, R.H., 1970. The oxidation of aqueous ferrous sulphate by Thiobacillus ferrooxidans, Can. J. Chem. Eng. 48, 669-676.

Mäkinen, J., Bachér, J., Kaartinen, T., Wahlström, M., Salminen, J., 2015. The effect of flotation and parameters for bioleaching of printed circuit boards. Minerals Engineering, 75, 26-31.

Mi, S., Song, J., Lin, J., Che, Y., Zheng, H., Lin, J., (2011). Complete genome of Leptospirillum ferriphilum ML-04 provides insight into its physiology and environmental adaptation. The Journal of Microbiology 49, 890-901.

Mrážiková, A., Kaduková, J., Marcinčáková, R., Velgosová, O., Willner, J., Fornalczyk, A., Saternus, M., 2016. The effect of specific conditions on $\mathrm{Cu}, \mathrm{Ni}, \mathrm{Zn}$ and $\mathrm{Al}$ recovery from PCBs waste using acidophilic bacterial strains, Arch. Metall. Mater., 61 (1), 261-264. 
Nie, H., Yang, C., Zhu, N., Wu, P., Zhang, T., Zhang, Y., Xing, Y., 2014. Isolation of Acidithiobacillus ferrooxidans strain Z1 and its mechanism of bioleaching copper from waste printed circuit boards. J Chem Technol Biotechnol, 90, 714-721.

Norris, P.R., 2007. Acidophile Diversity in Mineral Sulfide Oxidation. In: Rawlings D.E., Johnson D.B. (eds) Biomining. Springer, Berlin, Heidelberg.

Ojumu, T. V., Hansford, G. S., Petersen, J., 2009. The kinetics of ferrous-iron oxidation by Leptospirillum ferriphilum in continuous culture: The effect of temperature. Biochemical Engineering Journal 46, 161-168.

Ojumu, T. V., Petersen, J., 2011. The kinetics of ferrous ion oxidation by Leptospirillum ferriphilum in continuous culture: The effect of pH. Hydrometallurgy 106, 5-11.

Ojumu, T. V., Petersen, J., Hansford, G. S., 2008. The effect of dissolved cations on microbial ferrous-iron oxidation by Leptospirillum ferriphilum in continuous culture, Hydrometallurgy, 94, 69-76.

Priya, A., Hait, S., 2018. Extraction of metals from high grade waste printed circuit board by conventional and hybrid bioleaching using Acidithiobacillus ferrooxidans, Hydrometallurgy, In Press.

Rodrigues, M.L.M., Leão, V.A., Gomes, O., Lambert, F., Bastin, D., Gaydardzhiev, S., 2015. Copper extraction from coarsely ground printed circuit boards using moderate thermophilic bacteria in a rotating-drum reactor. Waste Management, 41, 148-158.

Silverman, M.P., Lundgren, D.G., 1959. Studies on the chemoautotrophic iron bacterium Ferrobacillus ferrooxidans I. An improved medium and a harvesting procedure for securing high cell yields J.Bacteriol, 77, 642-7.

Sinha, R., Chauhan, G., Singh, A., Kumar, A., Acharya, S., 2018. A novel eco-friendly hybrid approach for recovery and reuse of copper from electronic waste, Journal of Environmental Chemical Engineering, 6 (1), 1053-1061.

Svirko, L., Bashtan-Kandybovich, I., Karamanev, D., 2009. Experimental Study of Ferrous Iron Biooxidation by Leptospirillum Ferriphilum in Different Biofilm Reactors. Advanced Materials Research 71-73, 263-266.

Tuncuk, A., Stazi, V., Akcil, A., Yazici, E. Y., Deveci, H., 2012. Aqueous metal recovery techniques from e-scrap: Hydrometallurgy in recycling, Miner. Eng., 25, $28-37$. 
Wang, J., Bai, J., Xu, J., Liang, B., 2009. Bioleaching of metals from printed wire boards by Acidithiobacillus ferrooxidans and Acidithiobacillus thiooxidans and their mixture. Journal of Hazardous Materials, 172, 2-3, 1100-1105.

Wang, L., Li, Q., Li, Y., Sun, X., Li, J., Shen, J., Han, W., Wang, L. 2017. A novel approach for recovery of metals from waste printed circuit boards and simultaneous removal of iron from steel pickling waste liquor by two-step hydrometallurgical method, Waste Management, In Press.

Watling, H. R., Perrot, F. A., Shiers, D. W., 2008. Comparison of selected characteristics of Sulfobacillus species and review of their occurrence in acidic and bioleaching environments. Hydrometallurgy, 93, 57-65.

Xia, M.C., Wang, Y.P., Peng, T.J., Shen, L., Yu, R.L., Liu, Y.D., Chen, M., Li, J.K., Wu, X.L., Zeng, W.M., 2017. Recycling of metals from pretreated waste printed circuit boards effectively in stirred tank reactor by a moderately thermophilic culture, Journal of Bioscience and Bioengineering, In Press.

Xiang, Y., Wu, P., Zhu, N., Zhang, T., Liu, W., Wu, J., Li, P., 2010. Bioleaching of copper from waste printed circuit boards by bacterial consortium enriched from acid mine drainage, Journal of Hazardous Materials, 184, 812-818.

Yang, T., Xu, Z., Wen, J., Yang, L., 2009. Factors influencing bioleaching copper from waste printed circuit boards by Acidithiobacillus ferrooxidans. Hydrometallurgy, 97, 29-32.

Yang, Y., Chen, S., Li, S., Chen, M., Chen, H., Liu, B., 2014. Bioleaching waste printed circuit boards by Acidithiobacillus ferrooxidans and its kinetics aspect. Journal of Biotechnology, 173, 24-30.

Yue, G., Guezennec, A.G., Asselin, E., 2016. Extended validation of an expression to predict ORP and iron chemistry: Application to complex solutions generated during the acidic leaching or bioleaching of printed circuit boards, Hydrometallurgy, 164, 334-342.

Yue, G., Zhao, L., Olvera, O.G., Asselin, E., 2014. Speciation of the $\mathrm{H}_{2} \mathrm{SO}_{4}-\mathrm{Fe}_{2}\left(\mathrm{SO}_{4}\right)_{3}-$ $\mathrm{FeSO}_{4}-\mathrm{H}_{2} \mathrm{O}$ system and development of an expression to predict the redox potential of the $\mathrm{Fe}^{3+} / \mathrm{Fe}^{2+}$ couple up to $150{ }^{\circ} \mathrm{C}$, Hydrometallurgy, 147-148, 196-209.

Zhu, N., Xiang, Y., Zhang, T., Wu, P., Dang, Z., Li, P., Wu, J., 2011. Bioleaching of metal concentrates of waste printed circuit boards by mixed culture of acidophilic bacteria. Journal of Hazardous Materials, 192, 2, 614-619. 
Table 1: Continuous bio-oxidation studies - experimental conditions and performance.

\begin{tabular}{|c|c|c|c|c|c|c|c|c|}
\hline Strain & $\begin{array}{c}\mathrm{Fe}^{2+} \\
\left(\mathrm{g} \mathrm{L}^{-1}\right)\end{array}$ & Reactor & pH & $\begin{array}{l}\text { Temp } \\
\left({ }^{\circ} \mathrm{C}\right)\end{array}$ & $\begin{array}{l}\text { Hydraulic } \\
\text { residence } \\
\text { time }\end{array}$ & $\begin{array}{c}\text { Max } \\
\text { oxidation } \\
\text { rate }\left(\mathrm{mg} \mathrm{L}^{-1}\right. \\
\left.\mathbf{h}^{-1}\right) \\
\end{array}$ & $\begin{array}{c}\text { Study duration } \\
\text { (HRT = } \\
\text { hydraulic } \\
\text { residence time) }\end{array}$ & References \\
\hline $\begin{array}{c}A . \\
\text { ferrooxidans }\end{array}$ & 0.2 to 3 & $\begin{array}{l}\text { Stirred tank } \\
\text { reactor } 4 \mathrm{~L}\end{array}$ & 2.2 & 28 & 6 to $12.5 \mathrm{~h}$ & 420 & N.D. & $\begin{array}{c}\text { MacDonald and } \\
\text { Clark, } 1970\end{array}$ \\
\hline $\begin{array}{c}A . \\
\text { ferrooxidans }\end{array}$ & 5 to 9 & Chemostat $10 \mathrm{~L}$ & 2.3 & 32 & 7 to $91 \mathrm{~h}$ & 830 & 6 hours & $\begin{array}{c}\text { Guay and } \\
\text { Silver, } 1977\end{array}$ \\
\hline $\begin{array}{c}A . \\
\text { ferrooxidans }\end{array}$ & 3.5 to 4 & $\begin{array}{l}\text { Airlift } 1,3 \mathrm{~L} \text { with } \\
\text { polystyrene }\end{array}$ & $\begin{array}{l}1.8 \text { to } \\
2\end{array}$ & 27 & $\begin{array}{l}55 \mathrm{~min} \text { to } \\
12.5 \mathrm{~h}\end{array}$ & 1680 & 3 days & $\begin{array}{l}\text { Karamanev and } \\
\text { Nikolov, } 1986\end{array}$ \\
\hline $\begin{array}{c}A . \\
\text { ferrooxidans }\end{array}$ & 9 & Airlift $3 \mathrm{~L}$ & 1.3 & 30 & 8 to $50 \mathrm{~h}$ & 770 & $3 \mathrm{HRT}$ & $\begin{array}{c}\text { Halfmeier et al., } \\
1993 \mathrm{a}\end{array}$ \\
\hline $\begin{array}{c}A . \\
\text { ferrooxidans }\end{array}$ & 9 & $\begin{array}{l}\text { Airlift } 3 \text { L quartz } \\
\text { sand - sintered } \\
\text { glass rings }\end{array}$ & 1.3 & 30 & 8 to $50 \mathrm{~h}$ & 3600 & $\begin{array}{l}3 \text { HRT }-6 \\
\text { months }\end{array}$ & $\begin{array}{l}\text { Halfmeier et al., } \\
1993 b\end{array}$ \\
\hline \multirow[b]{2}{*}{$\begin{array}{c}A . \\
\text { ferrooxidans }\end{array}$} & \multirow[b]{2}{*}{1 to 8.5} & $\begin{array}{l}\text { Stirred tank } \\
\text { reactor } 5 \mathrm{~L}\end{array}$ & \multirow[b]{2}{*}{1.8} & \multirow[b]{2}{*}{30} & 16 to $100 \mathrm{~h}$ & 450 & \multirow[b]{2}{*}{$1 \mathrm{HRT}$} & \multirow[b]{2}{*}{$\begin{array}{l}\text { Gómez and } \\
\text { Cantero, } 2003\end{array}$} \\
\hline & & $\begin{array}{c}\text { Column } 1.35 \mathrm{~L} \\
\text { with Ni alloy } \\
\text { fibers }\end{array}$ & & & 4 to $12.5 \mathrm{~h}$ & 1100 & & \\
\hline $\begin{array}{l}\text { mixed culture } \\
\quad \text { with } L . \\
\text { ferrooxidans }\end{array}$ & 6.9 & $\begin{array}{c}\text { Fluidized bed } \\
\text { reactor } 0.9 \mathrm{~L} \text { with } \\
\text { activated charcoal } \\
320 \mathrm{~mL} \text { or } 365 \\
\mathrm{~mL}\end{array}$ & 1.1 & 37 & 0.2 to $0.6 \mathrm{~h}$ & 26400 & N.D. & $\begin{array}{l}\text { Kinnunen and } \\
\text { Puhakka, } 2004\end{array}$ \\
\hline \multirow{2}{*}{$\begin{array}{l}\text { mixed culture } \\
\quad \text { with } L \text {. } \\
\text { ferrooxidans }\end{array}$} & \multirow{2}{*}{7 to 21} & $\begin{array}{c}\text { Fluidized bed } \\
\text { reactor } 0.9 \mathrm{~L} \text { with } \\
\text { activated charcoal } \\
285 \mathrm{~mL}\end{array}$ & \multirow{2}{*}{1} & \multirow{2}{*}{35} & 3.4 to $4.8 \mathrm{~h}$ & \multirow{2}{*}{10000} & \multirow{2}{*}{ N.D. } & \multirow{2}{*}{$\begin{array}{l}\text { Kinnunen and } \\
\text { Puhakka, } 2005\end{array}$} \\
\hline & & $\begin{array}{c}\text { Fluidized bed } \\
\text { reactor } 0.4 \mathrm{~L} \text { with } \\
\text { activated charcoal } \\
120 \mathrm{~mL}\end{array}$ & & & 1.9 to $3.4 \mathrm{~h}$ & & & \\
\hline $\begin{array}{l}\text { mixed culture } \\
\text { with } L . \\
\text { ferrooxidans }\end{array}$ & 5.6 & $\begin{array}{l}\text { Airlift } 3 \text { L with } \\
\text { solid supports }\end{array}$ & $\begin{array}{l}0 \text { to } \\
1.8\end{array}$ & 30 & 0.25 to $4 \mathrm{~h}$ & 8100 & 3 months & $\begin{array}{l}\text { Ebrahimi et al., } \\
2005\end{array}$ \\
\hline L. ferriphilum & 5 & $\begin{array}{l}\text { Stirred tank } \\
\text { reactor } 1 \mathrm{~L}\end{array}$ & 1.3 & 42 & 7.8 to $67 \mathrm{~h}$ & 670 & 3+1 HRT & $\begin{array}{c}\text { Ojumu et al., } \\
2008\end{array}$ \\
\hline L. ferriphilum & 12 & $\begin{array}{l}\text { Stirred tank } \\
\text { reactor } 1 \mathrm{~L}\end{array}$ & 1.3 & $\begin{array}{c}18- \\
45\end{array}$ & 7.8 to $67 \mathrm{~h}$ & 900 & $3+1$ HRT & $\begin{array}{c}\text { Ojumu et al., } \\
2009 \\
\end{array}$ \\
\hline L. ferriphilum & 12 & $\begin{array}{l}\text { Stirred tank } \\
\text { reactor } 1 \mathrm{~L}\end{array}$ & $\begin{array}{l}0.8 \text { to } \\
2\end{array}$ & 42 & 10 to $66 \mathrm{~h}$ & 950 & $3+1$ HRT & $\begin{array}{c}\text { Ojumu and } \\
\text { Petersen, } 2011\end{array}$ \\
\hline $\begin{array}{c}L . \\
\text { ferrooxidans }\end{array}$ & 9 to 18 & Chemostat $1.25 \mathrm{~L}$ & 1.8 & 33.5 & 10 to $33 \mathrm{~h}$ & 1000 & $1 \mathrm{HRT}$ & $\begin{array}{c}\text { Bastías and } \\
\text { Gentina, } 2010\end{array}$ \\
\hline $\begin{array}{l}\text { mixed culture } \\
\text { with } L . \\
\text { ferrooxidans }\end{array}$ & 15 & $\begin{array}{c}\text { Stirred tank } \\
\text { reactor } 2 \text { stages } \\
\text { with settling }\end{array}$ & $\begin{array}{l}1.0 \text { to } \\
2.2\end{array}$ & 23 & 6 to $45 \mathrm{~h}$ & 1100 & 6 days & $\begin{array}{c}\text { Kaksonen et al., } \\
2014 \mathrm{a}\end{array}$ \\
\hline $\begin{array}{l}\text { mixed culture } \\
\text { with } L . \\
\text { ferrooxidans }\end{array}$ & 15 & $\begin{array}{l}\text { Airlift } 2 \text { stages } \\
\text { with settling }\end{array}$ & 1.5 & 23 & 8 to $45 \mathrm{~h}$ & $680-810$ & $5 \mathrm{HRT}$ & $\begin{array}{c}\text { Kaksonen et al., } \\
2014 \mathrm{c}\end{array}$ \\
\hline
\end{tabular}


Table 2: Bio-oxidation performances obtained with different ferrous iron concentrations $($ HRT $=12 \mathrm{~h}$; Mass of activated charcoal $=15 \mathrm{~g})$.

\begin{tabular}{cccc}
{$\left[\mathbf{F e}^{\mathbf{2 +}}\right]$ influent } & $\begin{array}{c}\text { Bio-oxidation } \\
\text { yield }\end{array}$ & Bio-oxidation rate & $\begin{array}{c}\text { Experiment } \\
\text { duration }\end{array}$ \\
$\left(\mathbf{g ~ L}^{-\mathbf{1}}\right)$ & $\mathbf{( \% )}$ & $\left(\mathbf{m g ~ L}^{-\mathbf{1}} \mathbf{h}^{-\mathbf{1}}\right)$ & $12 \mathrm{HRT}$ \\
\hline 1 & $100 \%$ & 83 & $18 \mathrm{HRT}$ \\
4.5 & $100 \%$ & 375 & $27 \mathrm{HRT}$ \\
6 & $21 \%-70 \%$ & $105-350$ & $44 \mathrm{HRT}$ \\
\hline
\end{tabular}


Table 3: Bio-oxidation rate $\left(\mathrm{r}_{\mathrm{b}} ; \mathrm{mg} \mathrm{L}^{-1} \mathrm{~h}^{-1}\right)$ and yield $\left(\mathrm{y}_{\mathrm{c}} ; \%\right)$ vs. activated charcoal mass at $6 \mathrm{~h}$ HRT for two different $\mathrm{Fe}^{2+}$ concentrations.

\begin{tabular}{ccccc} 
Activated & \multicolumn{2}{c}{$\left[\mathbf{F e}^{\mathbf{2 +}}\right]$ at $\mathbf{~} \mathbf{g} \mathbf{L}^{-\mathbf{1}}$} & \multicolumn{2}{c}{$\left[\mathbf{F e}^{\mathbf{2 +}}\right]$ at $\mathbf{9} \mathbf{g ~ L}^{-\mathbf{1}}$} \\
charcoal $(\mathbf{g})$ & $\mathrm{r}_{\mathrm{b}}\left(\mathrm{mg} \mathrm{L} \mathrm{h}^{-1}\right)$ & $\mathrm{y}_{\mathrm{c}}(\%)$ & $\mathrm{r}_{\mathrm{b}}\left(\mathrm{mg} \mathrm{L} \mathrm{h}{ }^{-1}\right)$ & $\mathrm{y}_{\mathrm{c}}(\%)$ \\
\hline 15 & 165 & $100 \%$ & $80-780$ & $6 \%-55 \%$ \\
30 & 165 & $100 \%$ & $650-1000$ & $40 \%-70 \%$ \\
45 & - & - & $500-1500$ & $35 \%-100 \%$ \\
\hline
\end{tabular}




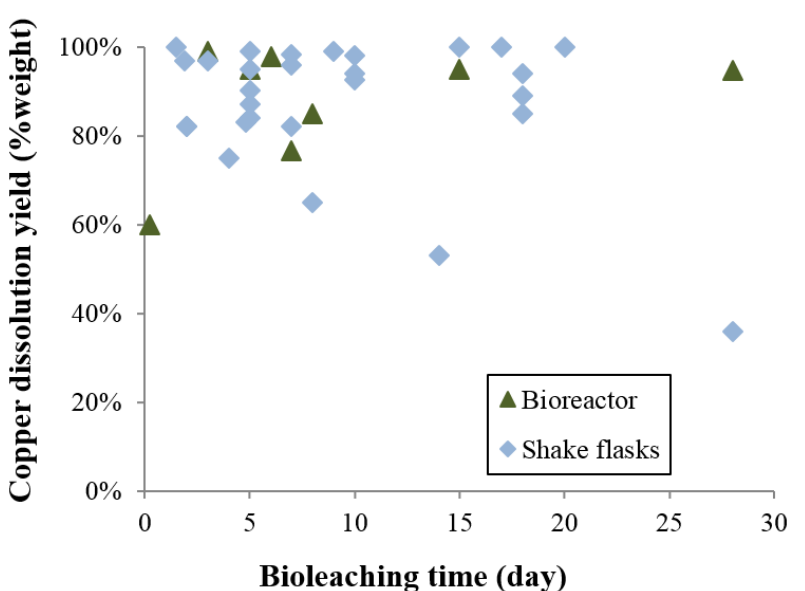

Arshadi and Mousavi, 2014 ; Liang et al., 2010 ;

Arshadi and Mousavi, 2015 ; Liang et al., 2013 ;

Bai et al., 2016 ;

Bas et al., 2013 ;

Brandl et al., 2001 ;

Bryan et al., 2015;

Chen et al., 2015 ;

Gu et al., 2014 ;

$\mathrm{Gu}$ et al., 2017a ;

$\mathrm{Gu}$ et al., 2017b ;

Guezennec et al., 2015 ;

Hong and Valix, 2014 ;

Ilyas et al., 2007 ;

Ilyas et al., 2013 ;

Ilyas and Lee, 2014 ;

Ișildar et al., 2015 ;

Karwowska et al., 2014 ;
Liang et al., 2016;

Mäkinen et al., 2015 ;

Mrážiková et al., 2016 ;

Nie et al., 2014 ;

Priya and Hait, 2017 ;

Rodrigues et al., 2015 ;

Sinha et al., 2018 ;

Wang et al., 2009;

Wang et al., 2017;

Xia et al., 2017 ;

Xiang et al., 2010 ;

Yang et al., 2009;

Yang et al., 2014 ;

Zhu et al., 2011.

Figure 1: Copper leaching yields versus bioleaching time in bioreactors and shake flasks in printed circuit boards bioleaching studies reported in the literature. 


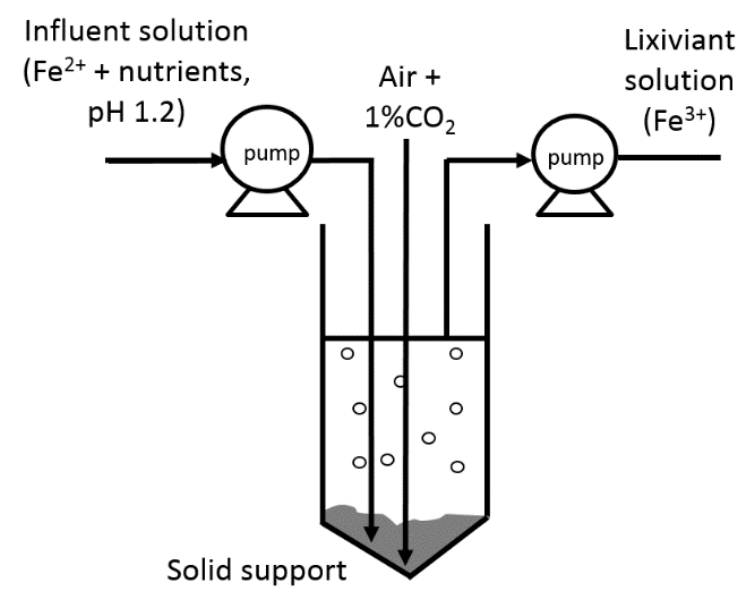

Figure 2: Schematic diagram of the bio-oxidation bubble column 

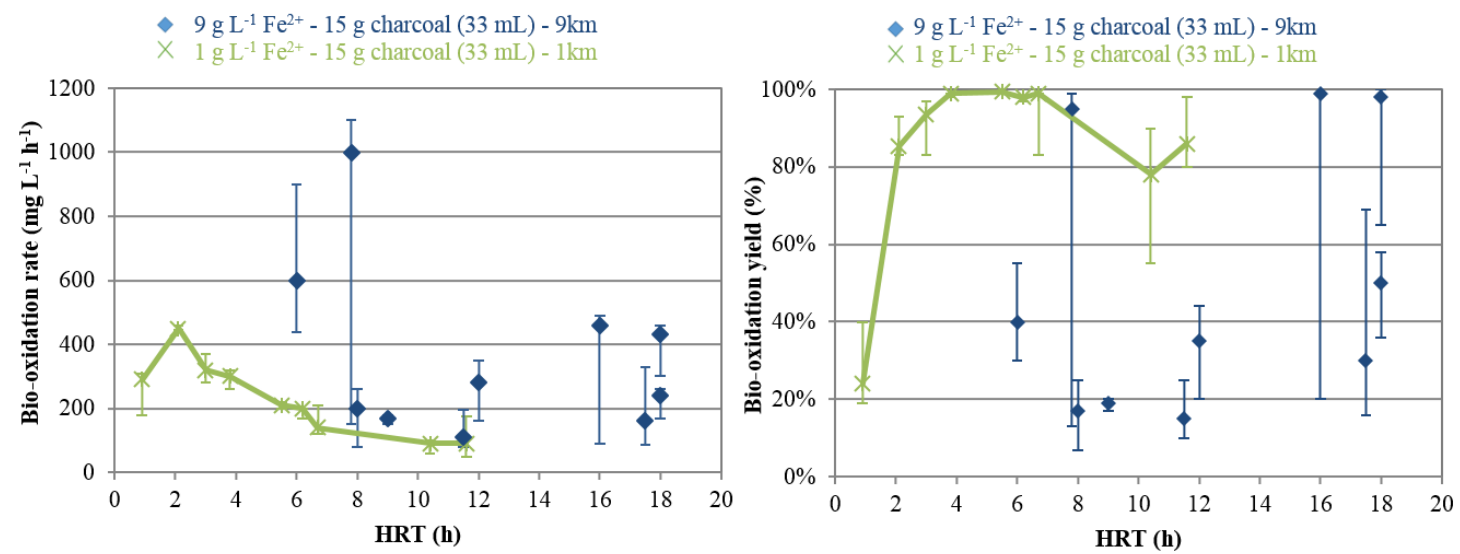

Figure 3: Ferrous iron bio-oxidation at various HRT comprised between 1 and 18 hours in $1 \mathrm{Km}$ and $9 \mathrm{Km}$ medium in the presence of $15 \mathrm{~g}$ of activated charcoal. Error bars depict the range of all obtained values at fixed operating conditions. 

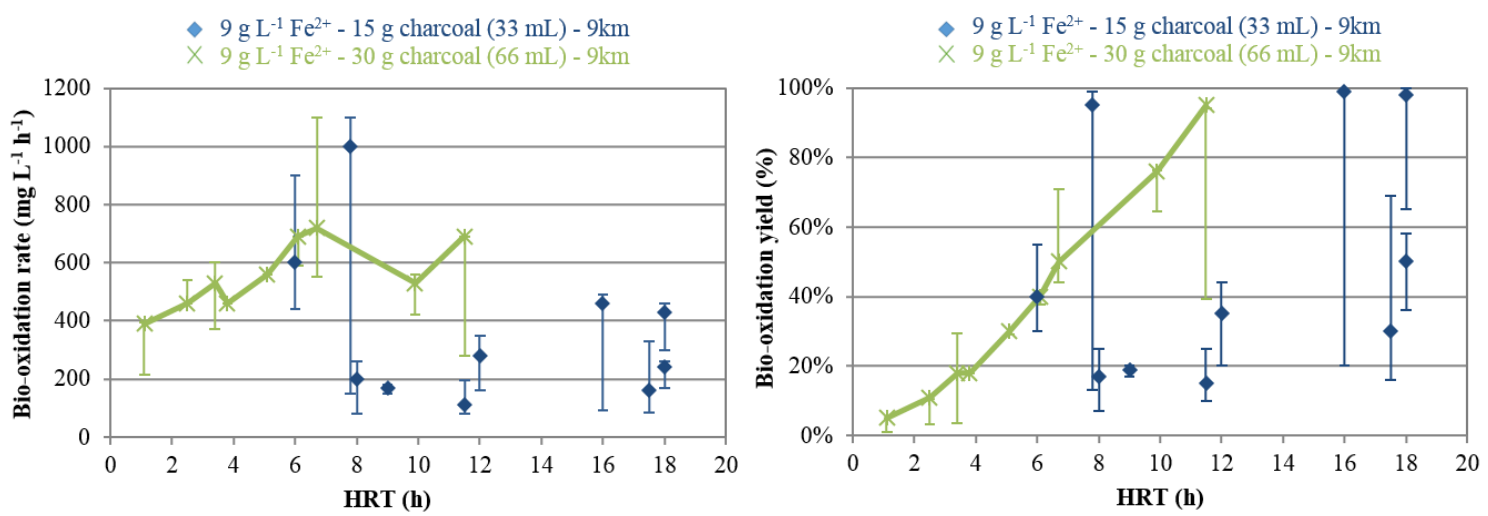

Figure 4: Ferrous iron bio-oxidation at various HRT in $9 \mathrm{Km}$ medium in the presence of $15 \mathrm{~g}$ and $30 \mathrm{~g}$ of activated charcoal. Error bars depict the range of all obtained values at fixed operating conditions. 

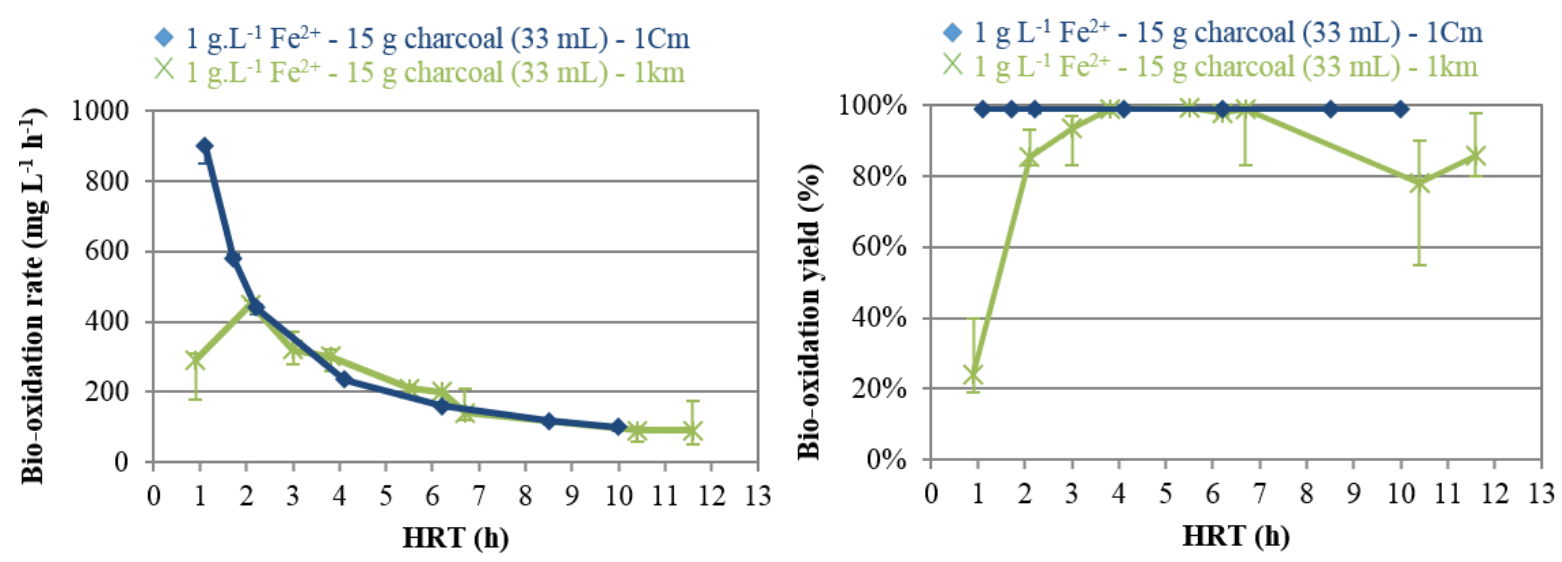

Figure 5: Ferrous iron bio-oxidation at various $H R T$ in $1 \mathrm{Km}$ and $1 \mathrm{Cm}$ media in the presence of $15 \mathrm{~g}$ of activated charcoal. Error bars depict the range of all obtained values at fixed operating conditions. 

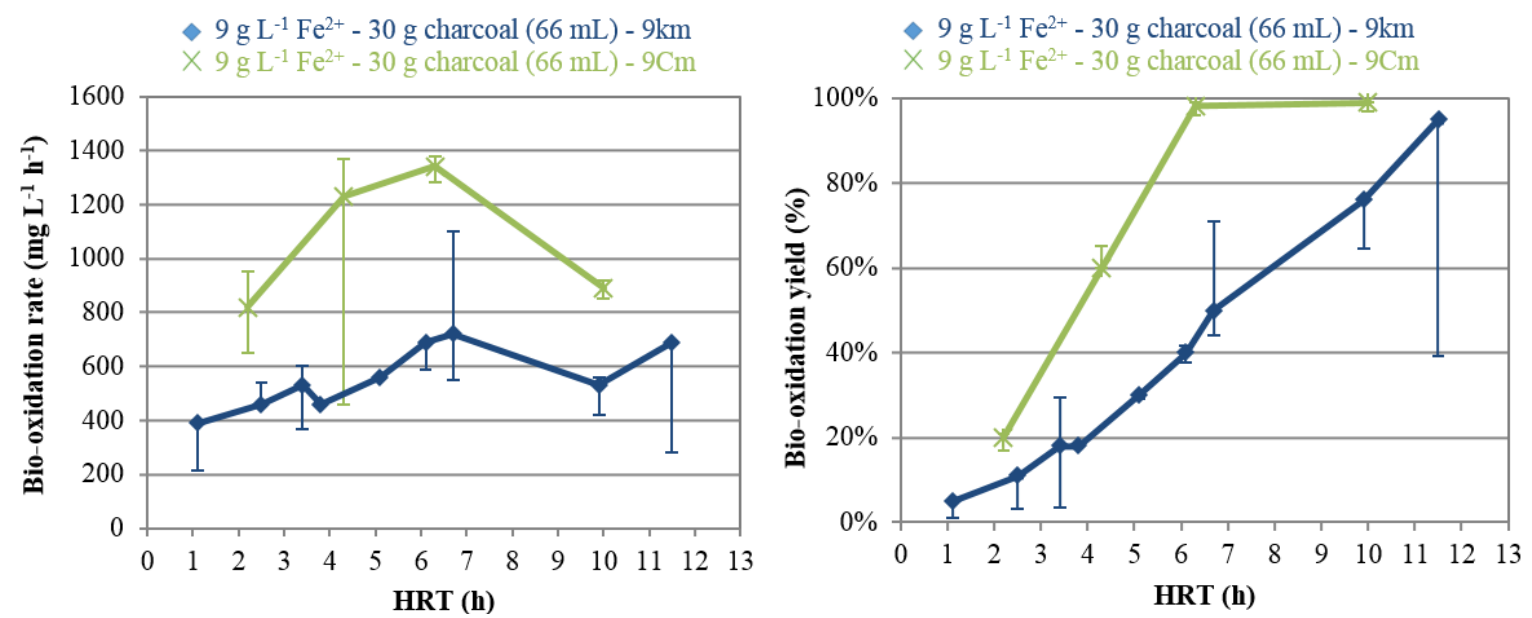

Figure 6: Ferrous iron bio-oxidation at various HRT in $9 \mathrm{Km}$ and $9 \mathrm{Cm}$ media in the presence of $30 \mathrm{~g}$ of activated charcoal. Error bars depict the range of all obtained values at fixed operating conditions. 

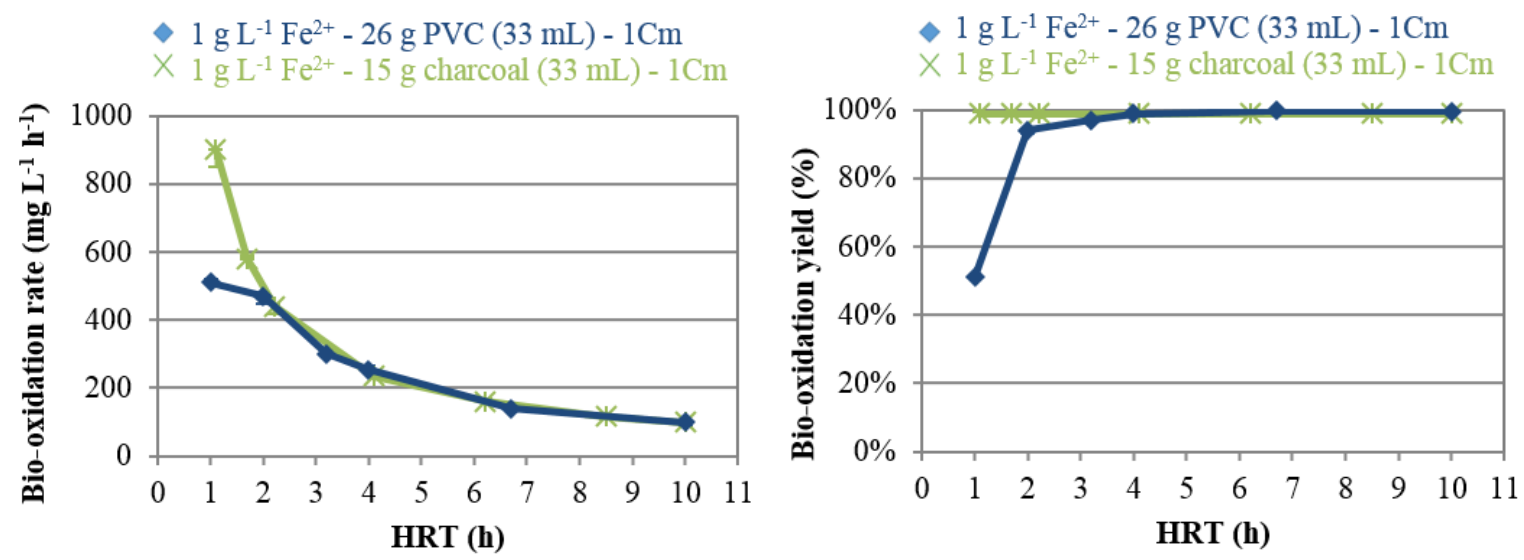

Figure 7: Ferrous iron bio-oxidation at various HRT in $1 \mathrm{Cm}$ medium in the presence of $26 \mathrm{~g}$ PVC or $15 \mathrm{~g}$ activated charcoal (apparent volumes $=33 \mathrm{~mL}$ ). Error bars depict the range of all obtained values at fixed operating conditions. 

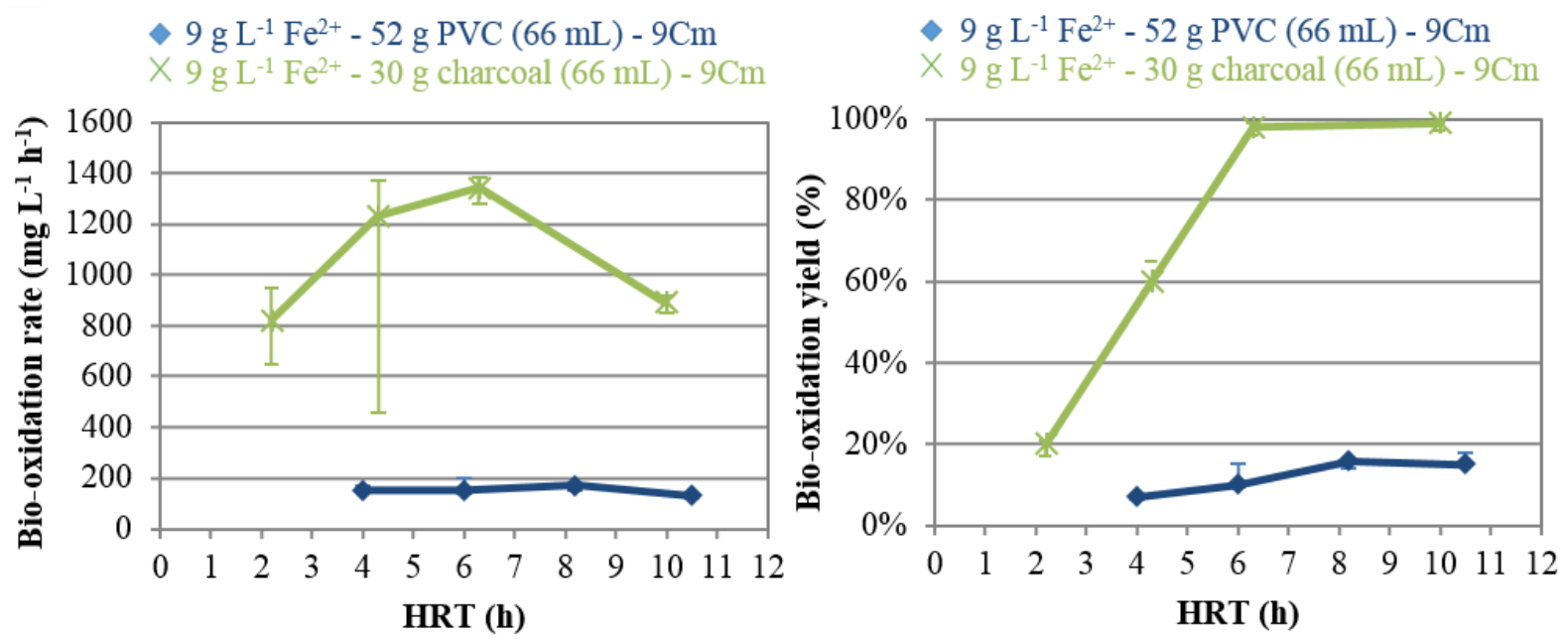

Figure 8: Ferrous iron bio-oxidation at various HRT in $9 \mathrm{Cm}$ medium in the presence of

$52 \mathrm{~g}$ of PVC or $30 \mathrm{~g}$ of activated charcoal (apparent volumes $=66 \mathrm{~mL}$ ). Error bars depict the range of all obtained values at fixed operating conditions. 

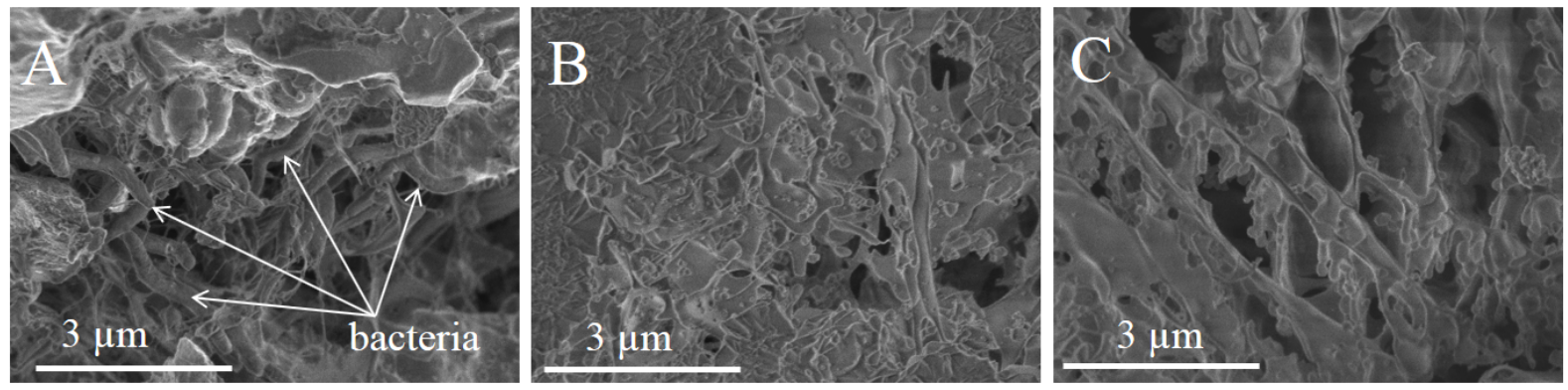

Figure 9: Cryo-SEM pictures inside of activated charcoal particles after colonization by acidophilic bacteria. Experimental conditions in $0 \mathrm{Km}$ in the presence of ferrous iron concentrations at $1 \mathrm{~g} \mathrm{~L}^{-1}(\mathrm{~A})$ and $9 \mathrm{~g} \mathrm{~L}^{-1}(\mathrm{~B})$. For (C), experiments were performed in an Erlenmeyer under abiotic conditions in the presence of $9 \mathrm{~g} \mathrm{~L}^{-1}$ ferric iron. 

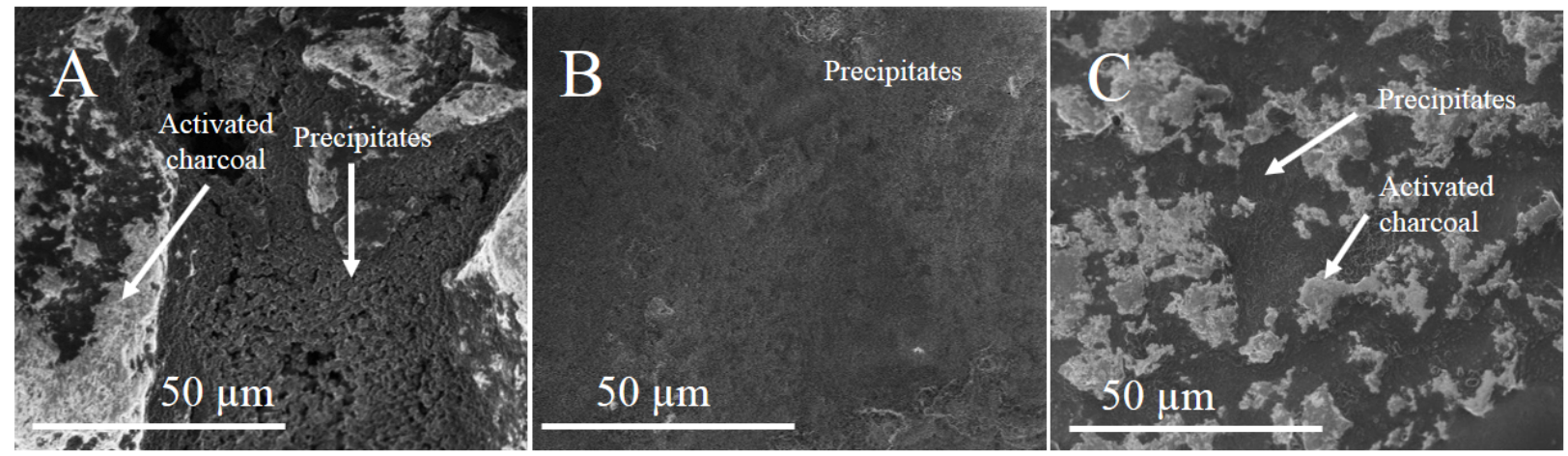

Figure 10: Cryo-SEM pictures of the surface of activated charcoal particles after colonization by acidophilic bacteria. Experimental conditions in $0 \mathrm{Km}$ in the presence of ferrous iron concentrations at $1 \mathrm{~g} \mathrm{~L}^{-1}$ (A) and $9 \mathrm{~g} \mathrm{~L}^{-1}$ (B). For (C), experiments were performed in an Erlenmeyer under abiotic conditions in the presence of $9 \mathrm{~g} \mathrm{~L}^{-1}$ ferric iron. 


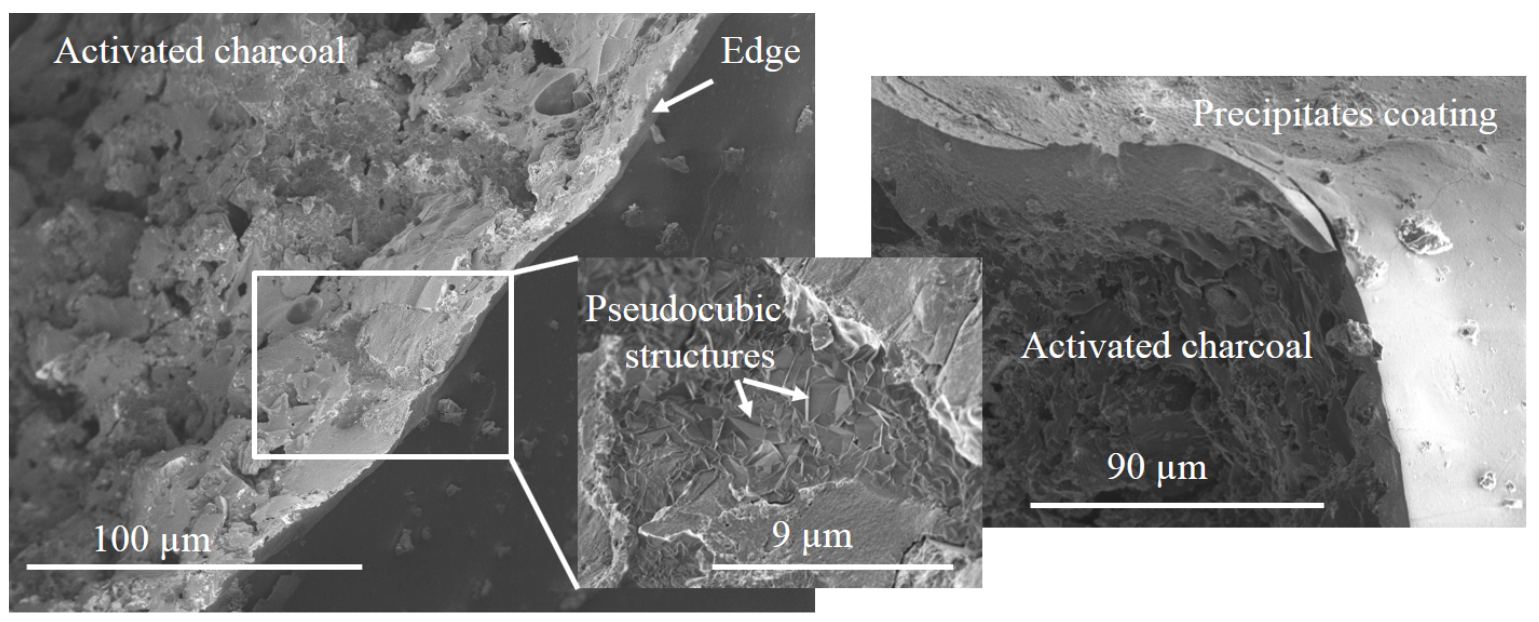

Figure 11: Cryo-SEM observations of the edge of a cryo-fractured particle of activated charcoal after colonization by acidophilic bacteria in $9 \mathrm{Km}$ in the presence of ferrous iron concentration of $9 \mathrm{~g} \mathrm{~L}^{-1}$. 

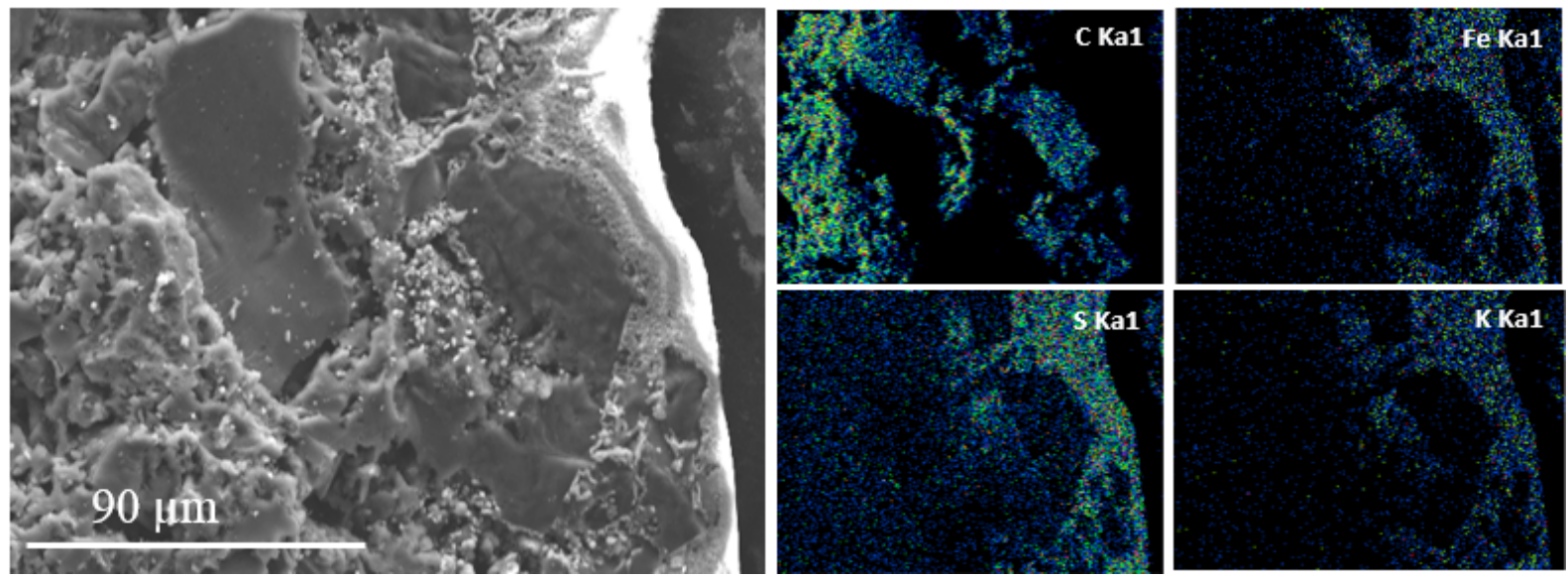

Figure 12: Cryo-SEM observation at $15 \mathrm{kV}$ and EDX cartography of the edge of a cryofractured particle of activated charcoal after colonization by acidophilic bacteria in $0 \mathrm{Km}$ in the presence of $9 \mathrm{~g} \mathrm{~L}^{-1}$ ferrous iron. 

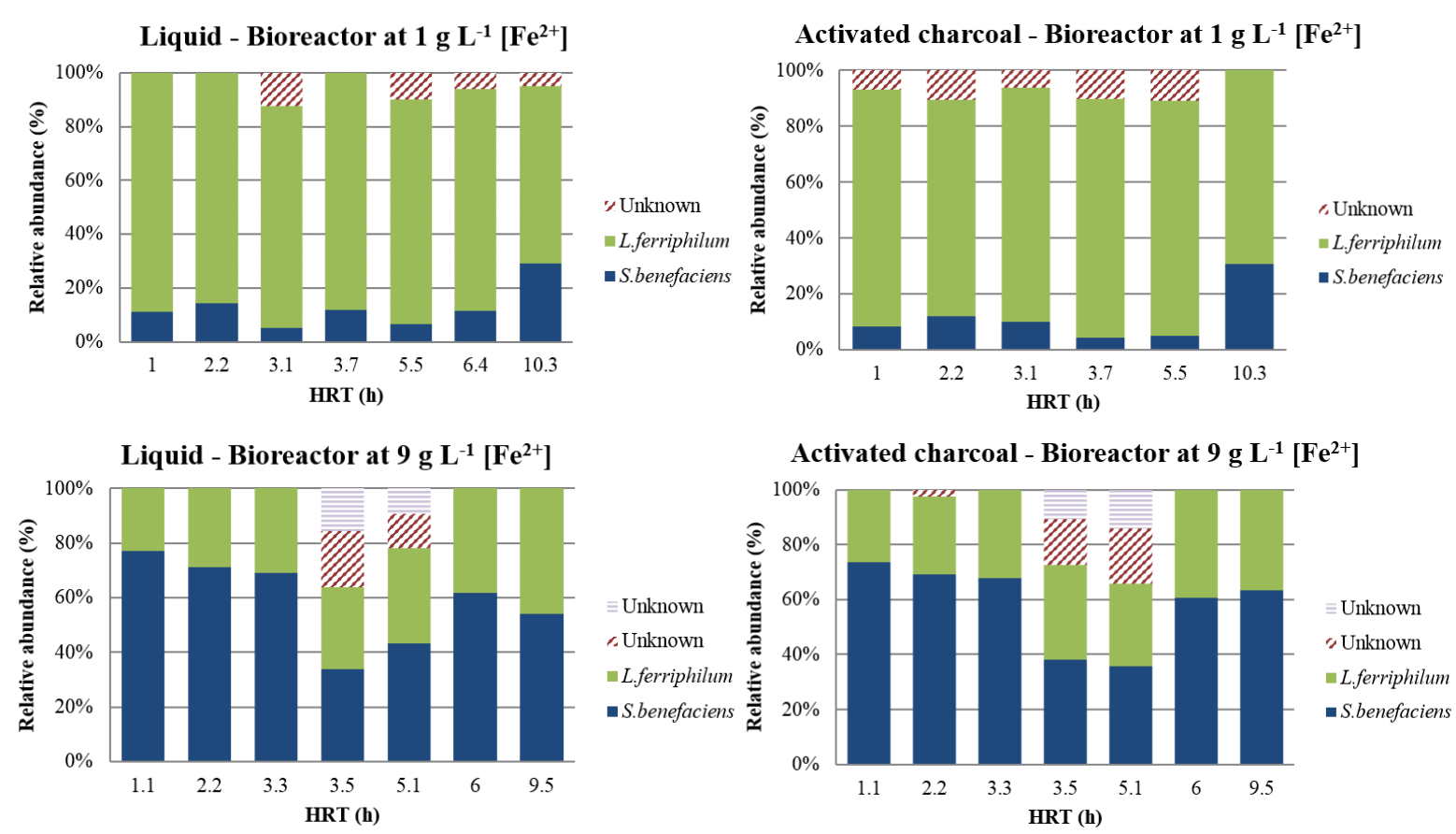

Figure 13: Comparison of bacterial diversity profiles for different HRT in liquid and solid phases (incoming ferrous iron concentrations $=1$ and $9 \mathrm{~g} \mathrm{~L}^{-1}$ in $0 \mathrm{Km}$ medium). 


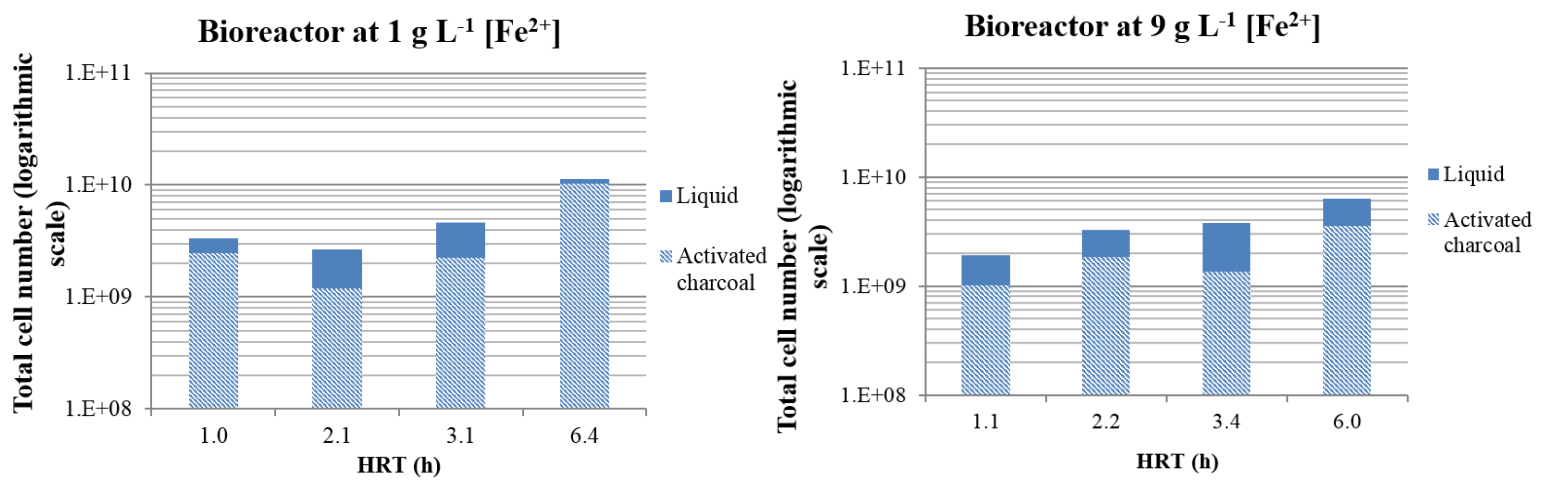

Figure 14: Total cell number in liquid and solid phases in bubble columns with influent with $1 \mathrm{~g} \mathrm{~L}^{-1} \mathrm{Fe}^{2+}$ and $15 \mathrm{~g}$ of activated charcoal as well as $9 \mathrm{~g} \mathrm{~L}^{-1} \mathrm{Fe}^{2+}$ and $30 \mathrm{~g}$ of activated charcoal in $0 \mathrm{Km}$ medium (logarithmic scale). 